Article

\title{
Are Valuable and Representative Natural Habitats Sufficiently Protected? Application of Marxan model in the Czech Republic
}

\author{
Ondřej Cudlín ${ }^{1}$, Vilém Pechanec ${ }^{2, *} \mathbb{D}$, Jan Purkyt ${ }^{1,3}$, Karel Chobot ${ }^{4}$, Luca Salvati ${ }^{5}$ and \\ Pavel Cudlín ${ }^{1}$ \\ 1 Global Change Research Institute of the Czech Academy of Sciences, Lipová 9, CZ-370 05 České Budějovice, \\ Czech Republic; cudlin.o@czechglobe.cz (O.C.); purkyt.j@czechglobe.cz (J.P.); cudlin.p@czechglobe.cz (P.C.) \\ 2 Department of Geoinformatics, Faculty of Science, Palacký University Olomouc, 17. listopadu 50, \\ CZ-771 46 Olomouc, Czech Republic \\ 3 Department of Plant Production and Agroecology, Faculty of Agriculture, University of South Bohemia in \\ České Budějovice, Studentská 1668, CZ-370 05 České Budějovice, Czech Republic \\ 4 Nature Conservation Agency, Kaplanova 1, CZ-148 00 Praha, Czech Republic; karel.chobot@nature.cz \\ 5 Council for Agricultural Research and Economics (CREA), Viale S. Margherita 80, I-52100 Arezzo, Italy; \\ luca.salvati@crea.gov.it \\ * Correspondence: vilem.pechanec@upol.cz; Tel.: +420-737-356-448
}

Received: 9 December 2019; Accepted: 2 January 2020; Published: 4 January 2020

\begin{abstract}
The joint impact of human activities and climate change on natural resources lead to biodiversity loss. Therefore, it is important to select protected areas through systematic conservation planning. The present study assessed how representative natural habitats are protected under the nature conservation network, and to identify new-but so far insufficiently-protected areas containing these habitats for sustainable management. We used the Marxan model to select the most valuable insufficiently protected natural habitats in the Czech Republic as a representative example for a conservation strategy for Central-Eastern European environments. We set three conservation targets $(25 \%, 50 \%$, and $75 \%)$, defining how much percent area of valuable representative natural habitats should be added to the area of the habitats already included in the Nature Protection Network. To implement these conservation targets it is necessary to preserve 22,932 ha, 72,429, ha and 124,363 ha respectively of the conservation targets occurring in the insufficiently protected areas, and 17,255 ha, 51,620 ha, and 84,993 ha respectively of the conservation features in the areas without protection status. Marxan was revealed to be an appropriate tool to select the most valuable and insufficiently protected natural habitats for sustainable management.
\end{abstract}

Keywords: biodiversity; nature habitats; protection level; conservation planning; Marxan model

\section{Introduction}

The increasing human population and the rising demand of natural resources as world domestic product, global tree cover loss, fossil fuel consumption, and increasing of carbon dioxide (CO2) emissions and increasing the temperature together with the impact of global climate change clearly and unequivocally show that the planet Earth is facing a climate emergency. It is essential to prevent the collapse of ecosystem functioning by protection and restoration of ecosystems and biodiversity $[1,2]$. Therefore, it is important to design protected areas to maintain minimally a present status of biodiversity. One way of promoting biodiversity conservation is to implement systematic conservation planning by effectively defining protected areas in both natural and agricultural landscapes. In addition, the newly designated protected areas can provide ecosystem services and biodiversity protection [3]. Climate 
change has brought uncertainties to conservation planning; therefore, species protection needs to model population changes based on climate models [4]. To help politicians, landscape planners, and managers in designating protected areas, it is important to make an inventory and a subsequent valuation of the required elements of biodiversity in the selected areas [5]. Currently, there are increasingly more reserves focusing on the protection of specific habitats for plant and animal species [6,7]. Goal setting depends on the degree of the biodiversity representativeness of a reserve in the area [8], and on its persistence-long-term survival of species and biodiversity elements in the protected area [9]. Some protected areas were selected based on the occurrence of very high biodiversity hotspots [10]. Systematic protective planning has fixed characteristics since it requires clearly defined biodiversity elements and detailed information about the existing protected areas [11,12]. Equally important is information about the design of reserves, e.g., perimeter boundaries or connectivity [12,13].

The Marxan model can be used to design new locations for systematic nature protection planning, and to select the elements that represent the biodiversity value in conservation planning [14]. Primarily, Marxan was created to update the boundaries of an official reserve at the Great Barrier Reef off the Queensland coast of Australia. Each reef corresponded to one planning unit, and the main conservation features were bioregions with a representation limit of $20 \%$ of their original area. Based on the results generated by Marxan, an enlargement of the original reserve with a fishing prohibition of more than $400 \mathrm{~km}^{2}$ was proposed [14]. Marxan was also used to design conservation areas in mangrove forests, around coral reefs, on beaches, and wetlands off the coast of Florida [15]. Reining et al. [16] used various ecological land units, e.g., wetlands, dry basins, river systems, steep slopes or mountain peaks, and top predator species such as lynx (Lynx lynx), wolf (Canis lupus), and marten (Marten sp.) as conservation features in the Apalachee Mountains. Meerman [6] proposed 16 habitat groups as primary conservation features in Belize, including habitats with protected and endangered species of birds, reptiles, fish, and flora. Munro [7] also suggested various types of habitats as conservation features: grass habitats, alpine tundra, and water habitats such as lakes, rivers, wetlands, and ponds. He also suggested habitats with endangered reptiles, birds, and mammal species in the Okanagan Valley, north of the Canadian-American border. Marxan was also used for conservation purposes on the islands of Indonesian Borneo [17] and in Papua New Guinea [18].

In the Czech Republic, protected areas form the Nature Protection Network (NPN) according to the national law dealing with nature and landscape conservation [19,20]. Nature protection is divided into species and territorial protection. Because the Marxan model works only with territorial protection, for its application in the Czech Republic we worked only with this issue. Our national categories of protected areas can be assigned to the categories of International Union for Conservation of Nature (IUCN). The large-scale protected areas include four National Parks (NPs) - three NPs belong to the category II and one NP to the category V-and 26 Landscape Protected Areas (LPAs) belonging to the category V. The small-scale protected areas included National Natural Reserves, National Natural Monuments, Nature Reserves and Nature Monuments correspond with the categories I, III, IV, V, but the categories III and IV dominate [19,21].

Land protection is guaranteed under Act No. 114/1992 Coll. on the Conservation of Nature and Landscape of the Czech Republic [19], and its implementing regulations are Decree 395/1992 Coll. [22] and Decree 45/2018 Coll. [23]. The accession to the European Union in 2004 determined the obligation to define the Natura 2000 network of protected areas. Both the Birds Directive [24] on the conservation of wild birds and the Habitats Directive [25] on the conservation of natural habitats and of wild fauna and flora were included in the national law. Especially the Habitats Directive and its processes work with the term sufficiency of coverage of habitats and species included in the Natura 2000 network. The sufficiency is based on arbitrary formal decisions while the Marxan model provides control over the results of such a formal process. In the Czech Republic, there are 41 Special Protection Areas (SPAs) and 1112 Special Areas of Conservation (SACs) defined in the Natura 2000 network, covering $14.1 \%$ of the total area of the Czech Republic [26]. Both areas (SPAs, SACs) are in the "not reported category" according to IUCN [21]. All the protected areas forming NPN extend 1,845,496 ha, 
i.e., $23 \%$ of country land. The Natura 2000 sites cover about $21 \%$ of the land and marine waters territory of the European Environment Agency's member countries and collaborating countries [27]. The European Environmental Agency (EEA) is responsible for developing The European Environment Information and Observation Network (Eionet) and coordinates its activities together with National Focal Points (NFPs) in the countries. The Eionet constellation is supplemented by seven European Topic Centres [28].

In our study, we divided the various categories of protected areas into sufficiently and insufficiently protected according to the level of habitat biodiversity protection (see Table 1). The distribution of protected areas in the Czech Republic is shown in Figure 1. The aim of our study was to assess how the valuable representative natural and near-natural habitats, identified by the national Habitat Mapping of the Czech Republic project, are protected under the nature conservation network, and to identify the new areas containing valuable natural habitats for sustainable management, not yet sufficiently protected.

Table 1. The status of Planning Units (PUs) based on the degree of protection under the Nature Protection Acts of the Czech Republic (Conserved—sufficiently protected areas, Available—insufficiently protected areas, Excluded-excluded from protection).

\begin{tabular}{|c|c|c|c|}
\hline $\begin{array}{l}\text { Categories of Territories } \\
\text { for Placement of } \\
\text { Planning Units (PUs) }\end{array}$ & Conserved & Available & Excluded \\
\hline \multirow[t]{3}{*}{ Characteristics } & $\begin{array}{l}\text { Existing functional } \\
\text { protection-Marxan } \\
\text { model does not work } \\
\text { with these PUs }\end{array}$ & $\begin{array}{l}\text { Insufficient or nonexistent } \\
\text { protection-Marxan model } \\
\text { selects PUs to complete the } \\
\text { protected network }\end{array}$ & $\begin{array}{l}\text { Excluded from the } \\
\text { protection-Marxan } \\
\text { model does not work } \\
\text { with these PUs }\end{array}$ \\
\hline & $\begin{array}{l}\text { 1st and 2nd zones of } \\
\text { National Parks (NPs), 1st } \\
\text { zone of Landscape }\end{array}$ & $\begin{array}{l}\text { 3rd zone of NP and } \\
\text { protection zone of NP, } \\
\text { 2nd-4th zones of LPAs, }\end{array}$ & \multirow{8}{*}{$\begin{array}{l}\text { Non-protected } \\
\text { territory (e.g., urban } \\
\text { and industrial areas, } \\
\text { roads, railways, } \\
\text { arable land) }\end{array}$} \\
\hline & $\begin{array}{l}\text { Protected Areas (LPAs), } \\
\text { National Natural }\end{array}$ & $\begin{array}{l}\text { National Natural Monument, } \\
\text { Nature Reserve and Nature }\end{array}$ & \\
\hline Conservation status & Reserve; areas of & Monument outside of NPs & \\
\hline & National Natural & and LPAs; Special Protection & \\
\hline & Monument, Natural & Areas (SPAs), Special Areas & \\
\hline & Reserve, Nature & of Conservation (SACs) and & \\
\hline & Monument situated in & the rest of the Czech & \\
\hline & the LPAs or NPs & Republic & \\
\hline
\end{tabular}




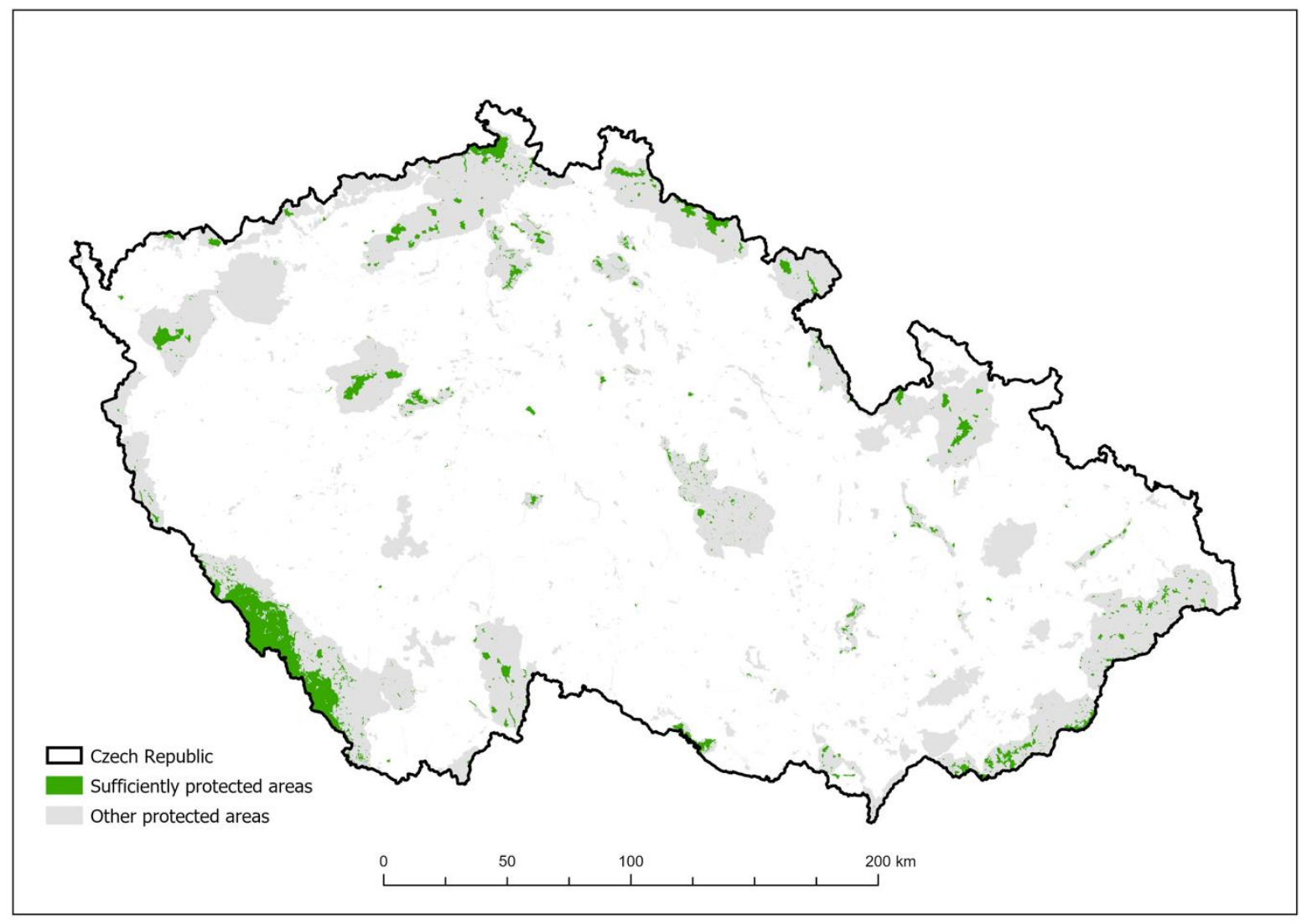

Figure 1. Protected areas creating the Nature Protection Network (NPN) according to the national law dealing with nature and landscape conservation in the Czech Republic.

\section{Materials and Methods}

\subsection{A Description of the Marxan Model}

The Marxan model was designed by Ball et al. [14] to plan new representative and spatially compact protection sites for landscape planning. The model uses a combination of Planning Units (PUs) that include all defined conservation features (CFs), minimising the total cost of the selected PUs. The Marxan model divides the area of interest into PUs that have either hexagonal or square meshes [29]. The PUs are divided into (i) conserved units—situated in sufficiently protected areas; (ii) available units—-which can be selected if they include suitable conservation features; (iii) excluded units-excluded from the selection (e.g., built-up areas). Areas with strict protection of habitats located in larger protected areas or having a larger protection zone around them are considered as sufficiently protected areas. This category includes: 1st and 2nd zones of NPs, 1st zone of LPAs, National Natural Reserve and small-scale plots of National Natural Monuments, Natural Reserves, and Nature Monuments, situated in the LPAs or NPs. The Marxan model uses the "object function" to calculate the optimal selection of PUs by comparing the selected combinations of PUs. For each combination of PUs, the software adds up the total costs needed to create them. It performs ongoing combination tests to achieve the lowest possible object function with the lowest costs.

The optimisation algorithm within Marxan attempts to find good systems of sites through simulated annealing, whereby different sets of potential conservation areas are compared with user-defined targets and costs, and the set of areas that achieves its objective most efficiently is determined. With the use of stochastic optimisation routines (simulated annealing) it generates spatial reserve systems that achieve particular biodiversity representation goals with reasonable optimality. Computationally, Marxan provides solutions to a conservation version of the $0-1$ knapsack problem, where the objects of interest are potential reserve sites with given biological attributes. The simulated 
annealing algorithm attempts to minimise the total cost of the reserve system, while achieving a set of conservation goals (typically that a certain percentage of each geographical/biological feature is represented by the reserve system). The object function of the total cost of the solution is calculated according to the following formula:

$$
\mathrm{C}=\sum C_{P U}+\sum S P F+\left(\sum C_{B L}\right) \times B L M
$$

C - total cost of the final design solution,

$\sum C_{P U}$ - the costs of all planning units involved in the solution,

$\sum S P F$ - total penalty for non-compliant conservation features,

$\sum C_{B L}$ - the length of the border surrounding the final protected area,

$B L M$ - a coefficient accounting for the complexity of the final protected area.

\subsection{Planning Units (PUs)}

Our analysis was carried out considering the whole of the Czech Republic as the study area. Country land was divided into PUs with a hexagonal net (edge of $310 \mathrm{~m}$, area of one hexagon was 25 ha) that were divided into three categories: conserved, available, and excluded. At the beginning of the analysis, the nature protection effectiveness of different types of protected areas in the Czech Republic was critically assessed [30] (Table 1). To describe PUs in the conserved category, we used data from the Nature Conservation Agency in the Czech Republic (NCA CR). To delineate PUs in the available category, ZABAGED and OpenStreetMap and NCA CR data were used, while for identifying PUs in the excluded category, ZABAGED and OpenStreetMap only were used. All data were in the scale 1:10,000 with a projection of EPSG 5514.

The PUs in the Nature Protection Network (NPN) of the Czech Republic with sufficient protection have been categorized as conserved units, see Table 1 . The excluded units included built-up areas, industrial areas, roads and their immediate surroundings. The Marxan model did not select any PUs from these categories. The rest of the Czech Republic was included in the available units (Table 1).

The cost of individual PUs was calculated as the weighted average of the point value of biodiversity determined by the Habitat Valuation Method (HVM) (see Table 1) for all natural and non-natural habitats [31-33]. The Boundary Length Modifier (BLM) parameter determines the length of PU borders. For the interfaces Conserved vs. Excluded and Available vs. Excluded, the length of the PUs was increased three times.

\subsection{Conservation Features}

The Conservation Feature $(\mathrm{CF})$ is a measurable, spatially defined element of biodiversity that is present in the final solution of the protected network; the CF is also included in the PU. CFs can be individual species and habitats, but also larger units such as biomes [34]. Each CF has a target which represents the minimum limit of $\mathrm{CFs}$ to be included in the final solution of the Marxan model. If the target is not met, the object function of the final solution is penalized.

We identified CFs as the natural and near-natural habitats of the Habitat Mapping from NCA CR [35]. The near-natural habitats represented habitats established by humans, but having species and structural diversity similar to nature habitats (e.g., cultural orchids meadows). Unit classification was defined by the Habitat Catalogue of the Czech Republic [36]. We used only those CFs which complied with the strict criteria of two quantitative parameters. The first parameter included (i) higher levels of representativeness and the well-protected status, and it was divided into the classes AA, AB, BA, $\mathrm{BB}$, for the habitats valuated according to the original Methods of Habitat Mapping of Natura 2000 and the Emerald Network in 2000-2009 [37], and (ii) representativeness and degradation, according to the methodology for updated valuation of habitats [38]. The second parameter for each habitat segment was the achievement of the minimum area necessary for ecosystem self-regulation, derived 
from the HVM method for each natural and near-natural habitat [31]. A total of 139 habitat types were identified as CFs, expressed in 149,906 segments and with a total area of 470,939 ha.

We created three scenarios representing the percent area of CFs included in the final proposal of the Marxan model to meet different protection targets $(25 \%, 50 \%$, and $75 \%)$, considering valuable habitats from all selected CFs in the Czech Republic. If part of the CF was already protected in the conserved PU, the protected area was deducted from the target area. The Marxan model selected the conservation features in hexagons with the highest biodiversity point values determined by the HVM method. If two hexagons had the same point value, the Marxan model chose a hexagon with a shorter boundary length than the edge of the PU.

\subsection{Technical Description of Marxan Calculations}

Our analysis was done in QGIS 3.6 and in the Marxan version 2.43 (64b). QGIS 3.6 was needed to pre-process spatial data and visualize the results. Each analysis was run in 20 steps with 1,000,000 iterations. To create input files with control parameters for Marxan, the Conservation Land-Use Zoning software (CLUZ) in QGIS was used. The CLUZ is a QGIS plugin that assists in designing protected area networks and other conservation landscapes [39]. After the simulation, we analysed how the PUs conform to the scenarios, and compared them with the rest of the existing network of protected areas in the Czech Republic. The compliance analysis was performed using GIS overlay operations.

\section{Results}

\subsection{PUs and Protection Scenarios}

The area of the Czech Republic for PUs was divided into 318,006 PUs with a total area of $7,950,150$ ha (Table 2). This area is larger than the original area of the Czech Republic (7,886,879 ha) because the model includes the hexagons that cross the national borders. Marxan unifies PUs (hexagons) into patches. The total number of patches was 897 , and the median patch area was 100 ha (Table 3). The smallest patch is an area of one PU containing at least one segment of a CF. The PUs in the available category covered the largest area; however, the PUs in the conserved category had the highest cost per ha according to HVM [31]. The most valuable habitats, defined in terms of their CFs, occupied an area of 470,939 ha, and made up $6 \%$ of the area of the Czech Republic. The spatial distribution of CFs and PUs is shown in Figure 2.

Table 2. Representation of the PU status in the Czech Republic and the value of biodiversity valuated with the Habitat Valuation Method (HVM) method [31].

\begin{tabular}{ccccc}
\hline Status & Total Area (ha) & $\begin{array}{c}\text { Total Cost } \\
\text { (million EUR) }\end{array}$ & $\begin{array}{c}\text { Cost Per 1 ha } \\
\text { (EUR) }\end{array}$ & Number of PUs \\
\hline Available & $4,460,875$ & 33,029 & 7404 & 178,435 \\
Conserved & 302,700 & 3561 & 11,764 & 12,108 \\
Excluded & $3,186,575$ & 19,910 & 6248 & 127,463 \\
Total & $7,950,150$ & 56,500 & 25,417 & 318,006 \\
\hline
\end{tabular}

Table 3. Number and area of the studied patches, Czech Republic.

\begin{tabular}{cc}
\hline Metric & Value \\
\hline Number of patches & 897 \\
Area of the smallest patch & $25 \mathrm{ha}$ \\
Median area of patches & $100 \mathrm{ha}$ \\
Area of the largest patch & $29,650 \mathrm{ha}$ \\
\hline
\end{tabular}






Figure 2. Distribution of Planning Units (PUs) containing Conservation Features (CFs) in the Czech Republic. The PUs are polygons which contain at least one segment of a CF. The CFs are the natural and near-natural habitats of the Habitat Mapping from Nature Conservation Agency in the Czech Republic (NCA CR). The PUs are divided into (i) conserved units-situated in sufficiently protected areas; (ii) available units-which can be selected if they include suitable conservation features; (iii) excluded units-excluded from the selection (e.g., built-up areas).

PUs containing valuable natural and near-natural habitats $(\mathrm{CFs})$ not yet conserved in protected areas were selected using the Marxan model (Table A1, Appendix A). To obtain a better overview of proposed new $\mathrm{CFs}$, we aggregated the selected valuable habitats into habitat formation groups with similar environmental conditions, e.g., all types of meadows to the grasslands group and all wetlands and peatbogs to the wetlands group [36] (Table 4). The largest area of natural and near-natural habitats was covered by beech and oak, and oak-hornbeam forests, and mesophilic meadows with an area in the range of 90,260 ha to 108,969 ha, respectively. The smallest area with rocks and rubble, natural Pinus mugo scrubs and alpine grasslands was found in the interval of 1242 ha to 1465 ha. The results show that the groups of habitats with the largest areas are not sufficiently protected over $50 \%$ of their area. A different situation was found for the following habitats: natural alpine grasslands, Pinus mugo scrubs, bog forests, spruce forests, peatbogs, and springs. These habitats are mostly protected over $50 \%$ of their area and for sufficient protection it is enough to add 392 ha. Groups of habitats with less than $10 \%$ of the total area sufficiently protected featured oak and oak-hornbeam forests, macrophytic vegetation of standing waters, alluvial forests, alluvial meadows and mesophilic meadows. Table 5 shows the required target areas for individual natural habitats classified as $\mathrm{CFs}$, to be added to the proposal of new protected areas according to the three scenarios. 
Table 4. The representation of the most valuable habitats selected as CFs in the total area of PUs and Conserved PUs. The all-natural and near-natural habitat codes are shown in Table 5, and abbreviations of these habitats according to the Habitat Catalogue of the Czech Republic [36] are reported in Table 3A in Appendix A.



Table 5. Required target area (ha) for habitats (CFs) to be added to the proposal of new conservation areas according to three target scenarios. The abbreviations of natural and near-natural habitats are formulated according to the Habitat Catalogue of the Czech Republic [36] and Table 3A in the Appendix A.

\begin{tabular}{|c|c|c|c|c|c|}
\hline $\begin{array}{l}\text { Habitat } \\
\text { Category }\end{array}$ & Formation & Natural and near Natural Habitats & $\begin{array}{c}\text { Scenario } \\
25 \%\end{array}$ & $\begin{array}{c}\text { Scenario } \\
50 \%\end{array}$ & $\begin{array}{c}\text { Scenario } \\
75 \%\end{array}$ \\
\hline \multirow{5}{*}{ Grasslands } & Alluvial meadows & R1.1, R1.2, T1.4, T1.5, T1.6, T1.7, T1.8, T1.9 & 4392.47 & $10,700.01$ & $17,007.53$ \\
\hline & Dry grasslands & $\begin{array}{c}\text { T3.1, T3.2, T3.3, T3.4, T3.5, T5.1, T5.2, T5.3, } \\
\text { T5.4, T5.5, T6.1, T6.2 }\end{array}$ & 997.1 & 2646.04 & 4400.03 \\
\hline & Mesic meadows & $\mathrm{T} 1.10, \mathrm{~T} 1.1, \mathrm{~T} 1.2, \mathrm{~T} 1.3, \mathrm{~T} 2.3, \mathrm{~T} 4.1, \mathrm{~T} 4.2$ & $17,921.57$ & $40,486.64$ & $63,051.72$ \\
\hline & Alpine grasslands & $\mathrm{A} 1.1, \mathrm{~A} 1.2, \mathrm{~A} 3, \mathrm{~A} 4.1, \mathrm{~T} 2.1, \mathrm{~T} 2.2$ & 32.92 & 110.33 & 188.65 \\
\hline & Heaths & A2.1, T8.1, T8.2, T8.3 & 87.83 & 277.66 & 470.73 \\
\hline \multirow{9}{*}{ Forests } & Alluvial forests & L1, L2.1, L2.2, L2.3, L2.4 & 7519.89 & $18,322.53$ & $29,137.23$ \\
\hline & $\begin{array}{l}\text { Oak and } \\
\text { oak-hornbeam } \\
\text { forests }\end{array}$ & $\begin{array}{l}\text { L3.1, L32, L3.3, L3.4, L6.1, L6.2, L6.3, L6.4, } \\
\text { L6.5, L7.1, L7.2, L7.3, L7.4 }\end{array}$ & $13,859.12$ & $36,670.07$ & $59,566.97$ \\
\hline & Ravine forests & $\mathrm{L} 4$ & 692.64 & 2775.46 & 4858.28 \\
\hline & Beech forests & L5.1, L5.2, L5.3, L5.4 & 4625.98 & $31,816.87$ & $59,059.1$ \\
\hline & Dry pine forests & L8.1, L8.2, L8.3 & 371.46 & 1570.91 & 2837.25 \\
\hline & Spruce forests & L9.1, L9.2, L9.3 & 0 & 382.52 & 6020.15 \\
\hline & Bog forests & L10.1, L10.2, L10.3, L10.4 & 0 & 39.74 & 369.47 \\
\hline & $\begin{array}{l}\text { Natural Pinus mugo } \\
\text { scrub }\end{array}$ & A7 & 0 & 0 & 0 \\
\hline & $\begin{array}{c}\text { Natural shrub } \\
\text { vegetation }\end{array}$ & $\mathrm{A} 2.2, \mathrm{~A} 8.1, \mathrm{~A} 8.2, \mathrm{~K} 1, \mathrm{~K} 2.1, \mathrm{~K} 2.2, \mathrm{~K} 3, \mathrm{~K} 4$ & 2965.76 & 7138.46 & $11,314.53$ \\
\hline
\end{tabular}


Table 5. Cont.

\begin{tabular}{cccccc}
\hline $\begin{array}{c}\text { Habitat } \\
\text { Category }\end{array}$ & Formation & Natural and near Natural Habitats & $\begin{array}{c}\text { Scenario } \\
\mathbf{2 5 \%}\end{array}$ & $\begin{array}{c}\text { Scenario } \\
\mathbf{5 0 \%}\end{array}$ & $\begin{array}{c}\text { Scenario } \\
\mathbf{7 5 \%}\end{array}$ \\
\hline \multirow{2}{*}{ Wetlands } & $\begin{array}{c}\text { Wetlands and litoral } \\
\text { vegetation } \\
\text { Peatbogs and springs }\end{array}$ & $\begin{array}{c}\text { A4.2, A4.3, M1.1, M1.2, M1.3, M1.4, M1.5, } \\
\text { M1.6, M1.7, M1.8, M2.1, M2.2, M2.3, M2.4, } \\
\text { M3, M4.1, M4.3, M5, M6, M7 } \\
\text { R1.31.4, R1.5, R2.1, R2.2, R2.3, R2.4, } \\
\text { R3.1, R3.2, R3.3, R3.4, T7 }\end{array}$ & 1170.26 & 3550.19 & 5946.22 \\
\hline $\begin{array}{c}\text { Macrophytic vegetation of standing } \\
\text { and flowing waters }\end{array}$ & V1, V2, V3, V4, V5, V6 & 7129.96 & $174,838.48$ & $294,252.02$ \\
\hline Rocks, Rubble & A5, A6, S1.1, S1.2, S1.3, S1.4, S1.5, S2 & 8.3 & 269.39 & 543.53 \\
\hline
\end{tabular}

\subsection{Assessment and Proposed Extension of the Protected Network}

The existing NPN in the Czech Republic is considered sufficient in the representation and distribution of individual types of protected areas. Nevertheless, even if a CF area of 73,805 ha, corresponding to $15.6 \%$ of all CFs, is included in the sufficiently protected part of the NPN, it is necessary to provide increased biodiversity protection for the remaining valuable natural habitats classified as CFs. According to our proposal including three scenarios to protect $25 \%, 50 \%$, or even $75 \%$ of CFs, it is necessary to conserve them in 22,932 ha, 72,429 ha, and 124,363 ha respectively in the insufficiently protected areas, and in 17,255 ha, 51,620 ha, and 84,993 ha respectively in the non-protected areas (Table 6).

Table 6. Final area (ha) and percent share in total area of all CFs of the most valuable habitats selected as CFs for the three scenarios.

\begin{tabular}{cccc}
\hline Area (ha, \%)/Scenarios & Scenario $\mathbf{2 5 \%}$ & Scenario $\mathbf{5 0 \%}$ & Scenario $\mathbf{7 5 \%}$ \\
\hline Final area (ha) and (\%) of CFs with insufficiently & $22,932.42$ & $72,428.55$ & $124,362.99$ \\
protected areas & 4.99 & 15.49 & 26.41 \\
Final area (ha) and (\%) of CFs without any protection & $17,255.01$ & $51,620.15$ & $84,993.43$ \\
Final area (ha) and (\%) of CFs with insufficiently & 3.66 & 10.96 & 18.05 \\
protected areas and without any protected areas & $40,187.43$ & $124,048.62$ & $209,356.29$ \\
\hline
\end{tabular}

For the Czech Republic, the Marxan model selected 3.66\%, 10.96\%, and $18.05 \%$ of the most valuable habitats without any protection according to our three scenarios. The largest non-protected land patches are situated mostly in the mountain forest areas along the borders of the Czech Republic and in military areas, e.g., in the Doupovské Mountains in Northwest Bohemia. To achieve the abovementioned scenarios, especially the scenario of adding valuable habitats to $75 \%$ of the area, Marxan selected and added isolated segments throughout the country (Figure 3). 


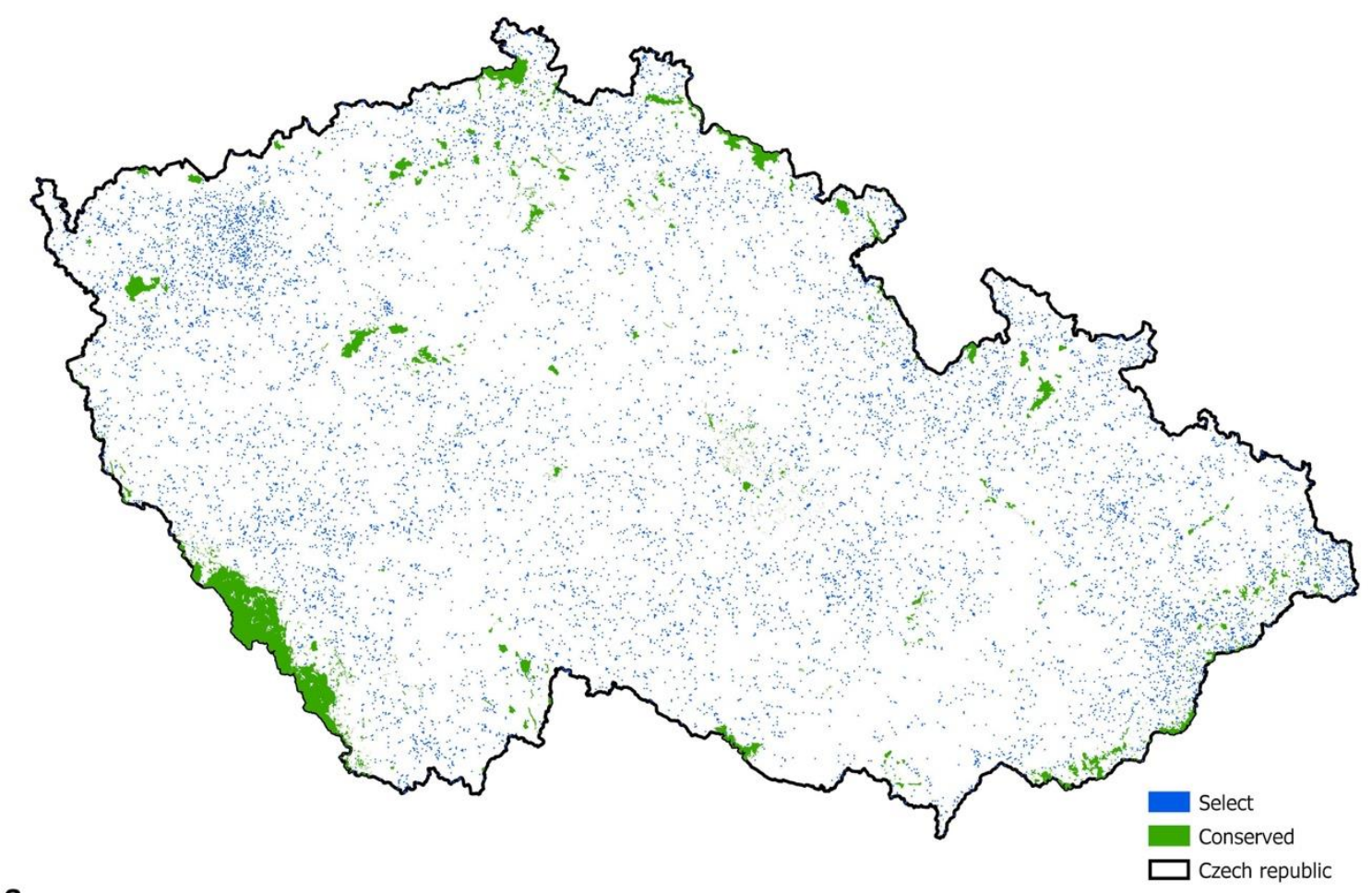

a

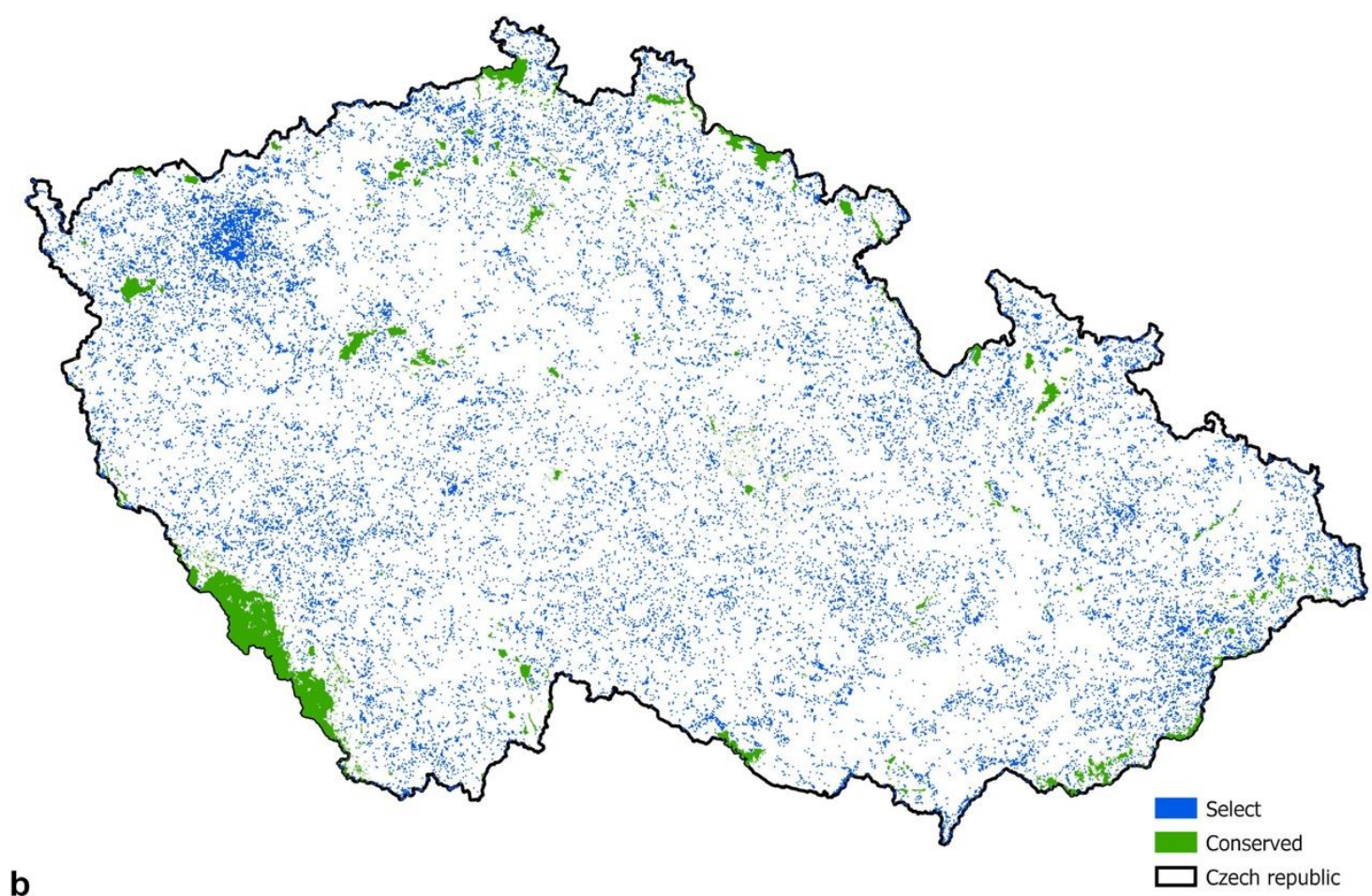

Figure 3. Cont. 


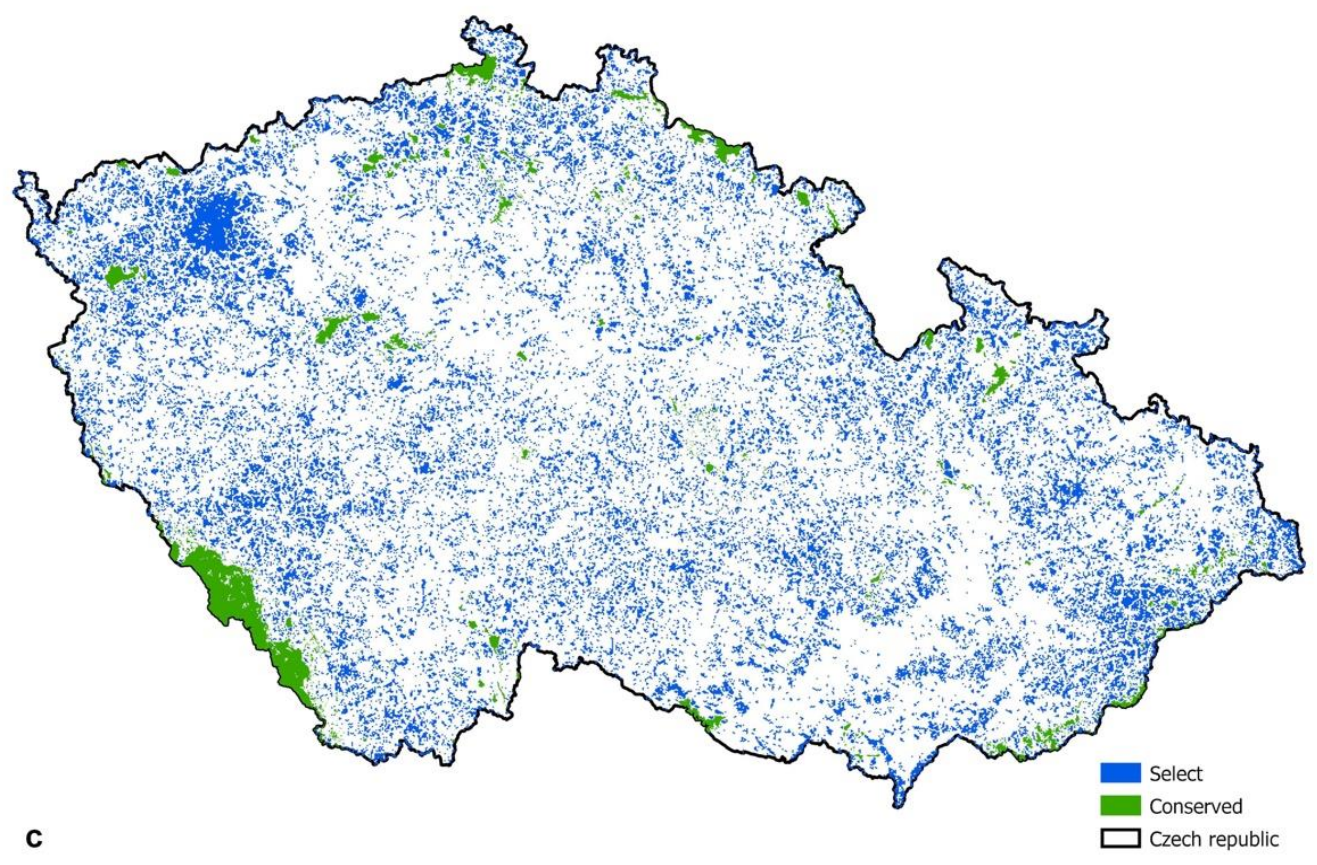

Figure 3. The planning units, including conservation features (CFs), in scenarios with the required areas of (a) $25 \%$, (b) $50 \%$, (c) $75 \%$ of the target planning units.

\section{Discussion}

Our results show that the most valuable habitats selected as CFs are included in the current NPN of the Czech Republic (Table 4). However, only some of the most valuable habitats are sufficiently protected in these areas, such as alpine grasslands (only A1.1-A8.2), bog forests (only L10.3, L10.4), wetlands (only M2.2), peat bogs and springs (only R1.5, R3.1), and Isoëtes vegetation (V6) (Table 5, and Table A2 in the Appendix A). According to the Habitat Catalogue of the Czech Republic [36], these selected habitats cover only a small area and have specific natural conditions. All these habitats (except for the habitats R1.4, R1.5 included in peat bogs and springs) belong to the network Natura 2000 sites, and they are included as SACs in the national law of the Czech Republic [19]. This network consists of important habitats that are protected by the member states of the European Union. These habitats are important for biodiversity conservation but, because of their small size, they have little impact on the Territorial System of Ecological Stability of the Landscape (TSES). The objective of planning and developing the TSES is to halt the unfavourable trend in the development of ecological stability and to hamper biodiversity loss in the culture according to Czech law No. 114/1992 [19]. However, our three scenarios show that the most of the remaining habitats are not sufficiently protected. Each scenario represents the percentage of CFs that should be included in the final proposal of Marxan to achieve the targets of $25 \%, 50 \%$, and $75 \%$ of all selected CFs. The most frequent habitats, covering large areas but with only $10 \%$ of the area sufficiently protected in NPN, belong mostly to the following habitats: Hercynian oak-hornbeam forests (L3.1), ash-alder alluvial forests (L2.2), willow-poplar forests of lowland rivers (L2.4), wet Filipendula grasslands (T1.6), intermittently wet Molinia meadows (T1.9), and mesophilic Arrhenatherum meadows (T1.1). According to Bastian [40], natural habitats occurring in insufficiently or non-protected areas, such as intermittently wet Molinia meadows (T1.9) and ash-alder alluvial forests (L2.2), are important for supplying ecosystem services, e.g., provisioning, regulating, and cultural services. The national Nature Conservation Agency evaluated the state and importance of the habitats included in the Natura 2000 sites in the years 2007 and 2013 in the Czech Republic. The Agency reported a higher number of important European habitats in 2013 compared to 2007, while admitting a possible estimation bias due to changes in assessment methods during this period. In addition, the number of habitats in an unfavourable state, translated into classification according to the Habitat Catalogue of the Czech Republic [36], e.g., macrophyte vegetation of water 
streams (V4), intermittently wet Molinia meadows (T1.9), and wet acidophilous oak forests (L7.2), has increased in the year 2017. All alpine grasslands were the only habitats with a better status (A1.1-A8.2) in the year 2017 [41].

The division of protected areas into sufficiently and insufficiently protected areas was carried out by our expert assessment, based on management of habitat biodiversity in protected areas and on the definition of protected areas in nature and landscape conservation law [19]. Sufficiently protected areas are large-scale sites where the main objective is to protect biodiversity and ecosystem processes and human intervention is excluded or strongly limited. Furthermore, some small-scale protected areas that are situated in the territory of large-scale protected areas and have a sufficiently large protection zone containing human disturbance, are also considered as sufficiently protected areas. Most sites in the Natura 2000 network tend to overlap with large-scale protected areas, such as NPs and LPAs. However, most of these overlapped areas include zones with low protection such as the 3rd zone of NPs and protection zone of NP, and 2nd to 4th zones of LPAs. In the case of significant habitats or species occurrence, a management contract can be signed with the landowner or tenant [19].

There are issues with the inefficient use of subsidies from the EU and insufficient control of nature protection by the central EU authorities [42], including problems with the non-functional compensation mechanism for private forests included in the Natura 2000 network [43]. According to Křenová and Kindlmann [42], the negative effects on Natura 2000 habitats and species are stronger in the states with the weak position of the state representatives, such as the Czech Republic or, more generally, Eastern European countries. Most of all, post-communist countries, e.g., Slovakia, Hungary and Romania, have been relatively unsuccessful in implementing Natura 2000 in agricultural landscapes. The main causes can be found in the discrepancy between local communities and authorities and the formal protection of sites, and the lack of financial support for management [44]. In addition, some habitats of European importance are fully or partly dependent on the continuation of traditional agricultural management [45].

The only important areas for biodiversity protection not included in the NPN are military training areas, including habitats with manmade irregular mechanical disturbances. These interventions result in fine-scaled mosaics of ecological conditions important for many species of plants and insects, above all butterflies [46]. Warren and Buttner [47] confirmed the importance of active military training areas as refuges for disturbance-dependent endangered insects in Germany. After the army abandoned these areas, their conservation value is threatened. To conserve the threatened species, Cizek et al. [46] recommended implementing alternative projects mimicking army activities, or sustainable management systems.

There are several ways to establish new protected areas in the Czech Republic: (1) by creating new protected areas in the currently most valuable unprotected habitats identified as CFs by Habitat Mapping of the Czech Republic (e.g., in previous military areas); (2) by connecting selected CFs with existing protected areas or their buffer zones, mostly in the forest mountainous regions along the state borders; (3) by improving the protection of insufficiently protected areas through effective financial investments [38] (e.g., supporting traditional mowing management for keeping valuable meadows [45,48] or using the regional seed mixtures [49]); (4) by supporting the natural species composition in near-natural forests by close-to-nature forest management (e.g., oak forests). This type of management leads to an emphasis on stability, productivity, diversity, and continuity of forest conditions [50].

The Marxan model has been used in a number of regional studies to design protected sites, including a wide range of habitats as anthropogenic land, terrestrial lowland forests, mangrove forests, mountain areas, lakes, the coral reef and open sea with a size of one PU of $10 \mathrm{~km}^{2}[6,7,16]$. In our study, we have reduced the scale of habitats such as grasslands, forests, wetlands, and water bodies to only $0.25 \mathrm{~km}^{2}$ for each PU. Our results show that it is possible to use Marxan for large areas with relatively detailed PUs. Further research should determine which scenario provides an optimal representation of 
valuable natural habitats, that is sufficient to maintain sustainable state of biodiversity in the cultural forest-agricultural landscape.

For better protection of biodiversity, it is also necessary to improve the connectivity among protected areas with different degrees of protection. The green infrastructures as a terrestrial ecosystem may play a key role in improving the coherence and resilience of protected areas [27]. For example, contractual agreements can be used to support the protection and connectivity of valuable habitats in insufficiently protected areas or in the areas without protection status at all. Three military territories with valuable habitats have been included in the Natura 2000 network as Special Protection Areas (SPAs) and Special Areas of Conservation (SACs), and at the same time they had the status of Contract Protected Area under Czech legislation. Another example is from the Landscape Protected Areas (LPA) Beskydy, where the forests of the Czech Republic manage the zone II of the LPA, overlapping with the SACs as a zone I of the LPA. In this case, forest owners may be supported by a financial contribution from landscape programs of the Ministry of the Environment.

Preliminary investigations on Natura 2000-protected areas suggest that there is now a relatively good spatial and functional connectivity among sites across national borders. The Alpine Network of Protected Areas (ALPARC) and the Carpathian Convention framework for protected areas are good examples of over-boundary cooperation. Both areas contain the large protected areas with another type of protection and both areas almost touch. Part of the Carpathian protected areas passes through the Czech Republic [27].

Results from the Marxan model can also serve to verify some categories of the Nature Protection Network (NPN). Not all types of protected areas have been proposed by the Ministry of the Environment of the Czech Republic on the basis of sufficient background data. At the same time, stakeholders such as foresters and farm holders, as well as fishing and hunting associations, should be involved in a sustainable management of near-natural agricultural and forestry management in natural valuable habitats [51-53]. Sustainable management is a conservation type of management containing appropriate procedures for conserving nature, e.g., extensive mowing and grazing, selective forest management, supported by subsidy funds from the Ministry of the Environment. Non-governmental organizations should also be involved in this issue, in particular by disseminating information on the importance of promoting valuable habitats in the cultural landscape to government officials and the general public.

\section{Conclusions}

The existing Nature Protection Network in the Czech Republic was found to be only partly adequate in terms of effective protection of representative valuable natural habitats mapped by the Nature Conservation Agency of the Czech Republic. A total area of 73,805 ha (15.6\%), of the most valuable natural habitats classified as $\mathrm{CFs}$, is sufficiently protected at present from the remaining $\mathrm{CF}$ area. Therefore, according to three conservation targets aimed at preserving $25 \%, 50 \%$, and $75 \%$ of the CFs, it is still necessary to preserve 22,932 ha, 72,429 ha, and 124,363 ha of the CFs included in the insufficiently protected area, and 17,255 ha, 51,620 ha, and 84,993 ha of the CFs in non-protected areas. The group of most valuable habitats that sufficiently protect more than $50 \%$ of their total area included small habitats with specific environmental conditions, e.g., alpine grasslands and bog forests. The sufficiently protected area of large-area habitats, such as oak and alluvial forests, alluvial and Mesic meadows, covered less than $10 \%$ of their total area. Nevertheless, these significantly represented habitats in the $\mathrm{CR}$ affected by human activity are still important for the provision of ecosystem services and require protection in the form of appropriate land management.

We proved that Marxan model is applicable over relatively large regions with relatively small size of planning units. The Marxan model is a candidate tool for verification of currently protected areas by the Nature Conservation Agency of the Czech Republic. According to our results, only large segments of valuable habitats without any protection have been found in military areas that are considered particularly important sites for biodiversity in Eastern Europe. Stakeholders managing the landscape and the non-governmental organizations should be involved in the protection of selected valuable 
habitats selected by the Marxan model in the insufficiently or even completely unprotected areas. A sustainable land management strategy promoting less intensive agriculture and close-to-nature forestry should be specifically designed for (and applied to) these areas. The Marxan model revealed itself to be a suitable tool for supporting large-scale strategic planning in larger administrative units up to the national scale in the Czech Republic.

Author Contributions: Conceptualization, V.P., O.C., J.P. and P.C.; methodology, V.P., L.S.; software, V.P.; validation, V.P., P.C.; formal analysis, V.P.; investigation, O.C., P.C.; resources, V.P.; data curtain, V.P.; writing- original draft preparation, O.C., L.S.; writing—review and editing, P.C., J.P., V.P, K.C.; visualization, V.P., O.C.; supervision, P.C.; project administration, P.C.; funding acquisition, P.C., V.P. All authors have read and agreed to the published version of the manuscript.

Funding: This work was supported by the Ministry of Education, Youth and Sports of the Czech Republic within the CzeCOS, grant number LM2015/061.

Acknowledgments: We would like to thank Lenka Štěrbová for preparation of the nature and near-nature habitat databases with assignment of the value and price according to Seják et al. [31].

Conflicts of Interest: The authors declare no conflict of interest.

\section{Appendix A}

Table A1. The most valuable habitats from Habitat Mapping Layers [35].

\begin{tabular}{|c|c|c|c|c|}
\hline $\begin{array}{l}\text { Habitats of the CR, } \\
\text { according Chytrý et al. } \\
\text { (2010) [33] }\end{array}$ & $\begin{array}{l}\text { Total Area } \\
\text { (ha) }\end{array}$ & $\begin{array}{c}\text { Area in Conserved } \\
\text { PU (ha) }\end{array}$ & $\begin{array}{l}\text { Area in Conserved } \\
\text { PU (Percentage) }\end{array}$ & $\begin{array}{c}\text { Number of All } \\
\text { Patches of Habitat } \\
\text { in the CZ }\end{array}$ \\
\hline A1.1 & 113.24 & 113.24 & 100 & 4 \\
\hline A1.2 & 593.08 & 583 & 98.3 & 4 \\
\hline A 2.1 & 51.64 & 51.64 & 100 & 2 \\
\hline A 2.2 & 223.5 & 211.2 & 94.5 & 4 \\
\hline A3 & 0.82 & 0.82 & 100 & 1 \\
\hline A 4.1 & 404.29 & 368.55 & 91.2 & 4 \\
\hline A 4.2 & 17.41 & 14.5 & 83.3 & 7 \\
\hline A 4.3 & 28.87 & 26.39 & 91.4 & 6 \\
\hline A5 & 1.29 & 1.29 & 100 & 2 \\
\hline A6 & 143.98 & 141.73 & 98.4 & 4 \\
\hline A7 & 1249.42 & 1186.19 & 94.9 & 2 \\
\hline A 8.1 & 0.94 & 0.94 & 100 & 1 \\
\hline A 8.2 & 23.58 & 23.58 & 100 & 2 \\
\hline $\mathrm{K} 1$ & 1811.64 & 288.6 & 15.9 & 100 \\
\hline K2.1 & 1111.67 & 148.58 & 13.4 & 28 \\
\hline K2.2 & 25.04 & 0.72 & 2.9 & 2 \\
\hline K3 & $13,734.43$ & 767.04 & 5.6 & 175 \\
\hline K4 & 19.8 & 8.09 & 40.9 & 4 \\
\hline $\mathrm{K} 4 \mathrm{C}$ & 1.72 & 0.66 & 38.4 & 1 \\
\hline L1 & 1850.71 & 262.22 & 14.2 & 49 \\
\hline L10.1 & 567.28 & 243.91 & 43 & 19 \\
\hline L10.2 & 1086.6 & 627.04 & 57.7 & 20 \\
\hline L10.3 & 39.96 & 36.67 & 91.8 & 6 \\
\hline L10.4 & 827.84 & 758.96 & 91.7 & 18 \\
\hline L2.1 & 180.33 & 57.13 & 31.7 & 26 \\
\hline L2.2 & $20,115.37$ & 1070.15 & 5.3 & 249 \\
\hline L2.2B & 9459.99 & 241.14 & 2.5 & 106 \\
\hline L2.3 & 7397.93 & 1045 & 14.1 & 23 \\
\hline L2.3B & 3432.37 & 534.1 & 15.6 & 9 \\
\hline $\mathrm{L} 2.4$ & 822.06 & 97.09 & 11.8 & 12 \\
\hline L3.1 & $35,284.14$ & 3475.36 & 9.8 & 95 \\
\hline L3.2 & 3977.74 & 157.44 & 4 & 10 \\
\hline
\end{tabular}


Table A1. Cont.

\begin{tabular}{|c|c|c|c|c|}
\hline $\begin{array}{l}\text { Habitats of the CR, } \\
\text { according Chytrý et al. } \\
(2010)[33]\end{array}$ & $\begin{array}{l}\text { Total Area } \\
\text { (ha) }\end{array}$ & $\begin{array}{c}\text { Area in Conserved } \\
\text { PU (ha) }\end{array}$ & $\begin{array}{l}\text { Area in Conserved } \\
\text { PU (Percentage) }\end{array}$ & $\begin{array}{c}\text { Number of All } \\
\text { Patches of Habitat } \\
\text { in the CZ }\end{array}$ \\
\hline L3.3 & $21,602.2$ & 2501.52 & 11.6 & 49 \\
\hline L3.4 & 2148.9 & 198 & 9.2 & 10 \\
\hline $\mathrm{L} 4$ & 8331.27 & 1390.18 & 16.7 & 128 \\
\hline L5.1 & $56,508.87$ & 9534.06 & 16.9 & 197 \\
\hline L5.2 & 288.08 & 123.37 & 42.8 & 11 \\
\hline L5.3 & 497.78 & 117.79 & 23.7 & 18 \\
\hline L5.4 & $51,674.22$ & $12,892.38$ & 24.9 & 218 \\
\hline L6.1 & 440.87 & 188.69 & 42.8 & 21 \\
\hline L6. 2 & 700.14 & 94.18 & 13.5 & 3 \\
\hline L6.3 & 500.32 & 0 & 0 & 0 \\
\hline L6.4 & 1591.64 & 137.95 & 8.7 & 21 \\
\hline L6.5A & 126.35 & 87.24 & 69 & 1 \\
\hline L6.5B & 3114.33 & 273.74 & 8.8 & 25 \\
\hline L7.1 & $13,717.97$ & 1075.72 & 7.8 & 60 \\
\hline L7.2 & 2740.75 & 105.3 & 3.8 & 14 \\
\hline L7.3 & 5617.85 & 900.87 & 16 & 57 \\
\hline L7.4 & 120.76 & 0 & 0 & 0 \\
\hline L8.1A & 476.29 & 290.34 & 61 & 9 \\
\hline L8.1B & 4615.27 & 813.1 & 17.6 & 46 \\
\hline L8.2 & 145.66 & 10.16 & 7 & 3 \\
\hline L8.3 & 36.9 & 4.74 & 12.8 & 3 \\
\hline L9.1 & $17,936.36$ & $10,960.8$ & 61.1 & 35 \\
\hline L9.2 & $12,386.42$ & 5810.69 & 46.9 & 77 \\
\hline L9.3 & 505.04 & 329.22 & 65.2 & 12 \\
\hline M1.1 & 5310.88 & 541.85 & 10.2 & 88 \\
\hline M1.2 & 35.1 & 3.02 & 8.6 & 1 \\
\hline M1.3 & 113.68 & 5.18 & 4.6 & 19 \\
\hline M1.4 & 406.67 & 114.96 & 28.3 & 31 \\
\hline M1.5 & 102.27 & 12.12 & 11.9 & 25 \\
\hline M1.6 & 19.53 & 3.37 & 17.3 & 12 \\
\hline M1.7 & 3012.91 & 459.76 & 15.3 & 126 \\
\hline M1.8 & 2.5 & 0 & 0 & 0 \\
\hline M2.1 & 364.19 & 70.58 & 19.4 & 6 \\
\hline M2.2 & 4.95 & 3.78 & 76.4 & 1 \\
\hline M2.3 & 3.09 & 0.71 & 23 & 2 \\
\hline M2.4 & 3.55 & 0 & 0 & 0 \\
\hline M3 & 12.06 & 5.89 & 48.8 & 3 \\
\hline M4.1 & 50.01 & 12.4 & 24.8 & 17 \\
\hline M4.3 & 0.63 & 0 & 0 & 0 \\
\hline M5 & 109.02 & 9.38 & 8.6 & 23 \\
\hline M6 & 12.04 & 1.48 & 12.3 & 2 \\
\hline M7 & 26.19 & 1.29 & 4.9 & 2 \\
\hline R1.1 & 4.67 & 0.76 & 16.3 & 12 \\
\hline R1.2 & 21.62 & 2.32 & 10.7 & 17 \\
\hline R1.3 & 6.79 & 1.44 & 21.2 & 16 \\
\hline R1.4 & 273.45 & 51.75 & 18.9 & 128 \\
\hline R1.5 & 3.5 & 3.44 & 98.3 & 5 \\
\hline $\mathrm{R} 2.1$ & 17.32 & 0.81 & 4.7 & 6 \\
\hline $\mathrm{R} 2.2$ & 923.92 & 313.69 & 34 & 80 \\
\hline $\mathrm{R} 2.3$ & 1564.66 & 733.94 & 46.9 & 84 \\
\hline $\mathrm{R} 2.4$ & 9.24 & 6.19 & 67 & 4 \\
\hline R3.1 & 360.07 & 273.47 & 75.9 & 23 \\
\hline R3.2 & 1511.92 & 1060.59 & 70.1 & 14 \\
\hline R3.3 & 38.52 & 22.45 & 58.3 & 13 \\
\hline R3.4 & 279.63 & 47.01 & 16.8 & 9 \\
\hline S1.1 & 35.96 & 3.48 & 9.7 & 19 \\
\hline
\end{tabular}


Table A1. Cont.

\begin{tabular}{|c|c|c|c|c|}
\hline $\begin{array}{l}\text { Habitats of the CR, } \\
\text { according Chytrý et al. } \\
\text { (2010) [33] }\end{array}$ & $\begin{array}{l}\text { Total Area } \\
\text { (ha) }\end{array}$ & $\begin{array}{c}\text { Area in Conserved } \\
\text { PU (ha) }\end{array}$ & $\begin{array}{l}\text { Area in Conserved } \\
\text { PU (Percentage) }\end{array}$ & $\begin{array}{c}\text { Number of All } \\
\text { Patches of Habitat } \\
\text { in the CZ }\end{array}$ \\
\hline S1.2 & 1004.58 & 262.93 & 26.2 & 149 \\
\hline S1.3 & 13.83 & 1.34 & 9.7 & 3 \\
\hline S1.4 & 1.62 & 0.06 & 3.7 & 1 \\
\hline S1.5 & 7.08 & 1.82 & 25.7 & 8 \\
\hline S2A & 10.22 & 3.78 & 37 & 6 \\
\hline S2B & 23.28 & 5.49 & 23.6 & 7 \\
\hline S3 & 0.84 & 0.34 & 40.5 & 2 \\
\hline $\mathrm{T} 1.1$ & $65,935.86$ & 2862.18 & 4.3 & 325 \\
\hline $\mathrm{T} 1.10$ & 169.88 & 16.4 & 9.7 & 32 \\
\hline $\mathrm{T} 1.2$ & 5771.62 & 588.67 & 10.2 & 42 \\
\hline T1.3 & 15421.3 & 637.22 & 4.1 & 89 \\
\hline T1.4 & 5976.69 & 277.74 & 4.6 & 36 \\
\hline $\mathrm{T} 1.5$ & $11,593.79$ & 1000.32 & 8.6 & 219 \\
\hline T1.6 & 4448.57 & 357.46 & 8 & 112 \\
\hline $\mathrm{T} 1.7$ & 367.28 & 0.98 & 0.3 & 2 \\
\hline T1.8 & 3.2 & 0 & 0 & 0 \\
\hline T1.9 & 2814.32 & 275.49 & 9.8 & 66 \\
\hline $\mathrm{T} 2.1$ & 43.48 & 31.7 & 72.9 & 5 \\
\hline $\mathrm{T} 2.2$ & 309.62 & 44.48 & 14.4 & 4 \\
\hline $\mathrm{T} 2.3$ & 2669.61 & 511.02 & 19.1 & 101 \\
\hline T3.1 & 103.98 & 33.19 & 31.9 & 22 \\
\hline T3.2 & 27.76 & 7.83 & 28.2 & 10 \\
\hline T3.3 & 251.66 & 54.18 & 21.5 & 13 \\
\hline T3.3D & 453.73 & 43.84 & 9.7 & 19 \\
\hline T3.4 & 445.49 & 237.16 & 53.2 & 13 \\
\hline $\mathrm{T} 3.4 \mathrm{~B}$ & 92.87 & 3.91 & 4.2 & 3 \\
\hline $\mathrm{T} 3.4 \mathrm{D}$ & 3798 & 458.24 & 12.1 & 61 \\
\hline T3.5A & 13.08 & 2.46 & 18.8 & 1 \\
\hline $\mathrm{T} 3.5 \mathrm{~B}$ & 667.26 & 9.83 & 1.5 & 8 \\
\hline $\mathrm{T} 4.1$ & 53.71 & 10.51 & 19.6 & 19 \\
\hline $\mathrm{T} 4.2$ & 238.35 & 17.52 & 7.4 & 45 \\
\hline T5.1 & 21.37 & 0.4 & 1.9 & 1 \\
\hline T5.2 & 71.38 & 1.41 & 2 & 2 \\
\hline T5.3 & 379.65 & 32.82 & 8.6 & 8 \\
\hline T5.4 & 65.22 & 0 & 0 & 0 \\
\hline T5.5 & 553.13 & 9.67 & 1.7 & 22 \\
\hline T6.1 & 14.65 & 2.54 & 17.3 & 1 \\
\hline T6.2 & 114.37 & 7.7 & 6.7 & 4 \\
\hline $\mathrm{T} 7$ & 25.66 & 5.03 & 19.6 & 2 \\
\hline T8.1 & 83.55 & 24.13 & 28.9 & 5 \\
\hline $\mathrm{T} 8.2$ & 648.54 & 77.87 & 12 & 30 \\
\hline T8.3 & 40.18 & 6.47 & 16.1 & 6 \\
\hline V1 & 46.07 & 0.89 & 1.9 & 4 \\
\hline $\mathrm{V} 1 \mathrm{~F}$ & 3455.98 & 395.75 & 11.5 & 59 \\
\hline V1G & $12,039.25$ & 807.11 & 6.7 & 103 \\
\hline $\mathrm{V} 2$ & 134.46 & 3.03 & 2.3 & 4 \\
\hline V3 & 14.84 & 9.83 & 66.2 & 7 \\
\hline V4A & 1942.2 & 226.04 & 11.6 & 33 \\
\hline V4B & 3454.88 & 265.18 & 7.7 & 90 \\
\hline V5 & 12.72 & 0.02 & 0.2 & 2 \\
\hline V6 & 25.38 & 25.38 & 100 & 2 \\
\hline
\end{tabular}


Table A2. Required target area (ha) to be added to each scenario. The habitats were selected from Habitat Mapping Layers [35].

\begin{tabular}{|c|c|c|c|}
\hline Habitat & $\begin{array}{c}\text { Required Area to Complete } \\
\text { for Scenario } 25 \%\end{array}$ & $\begin{array}{c}\text { Required Area to Complete } \\
\text { for Scenario } 50 \%\end{array}$ & $\begin{array}{c}\text { Required Area to Complete } \\
\text { for Scenario } 75 \%\end{array}$ \\
\hline A1.1 & 0 & 0 & 0 \\
\hline A1.2 & 0 & 0 & 0 \\
\hline A2.1 & 0 & 0 & 0 \\
\hline A2.2 & 0 & 0 & 0 \\
\hline A3 & 0 & 0 & 0 \\
\hline A4.1 & 0 & 0 & 0 \\
\hline A 4.2 & 0 & 0 & 0 \\
\hline A4.3 & 0 & 0 & 0 \\
\hline A5 & 0 & 0 & 0 \\
\hline A6 & 0 & 0 & 0 \\
\hline A7 & 0 & 0 & 0 \\
\hline A8.1 & 0 & 0 & 0 \\
\hline A8. 2 & 0 & 0 & 0 \\
\hline $\mathrm{K} 1$ & 164.31 & 617.22 & 1070.12 \\
\hline K 2.1 & 129.34 & 407.26 & 685.18 \\
\hline K2.2 & 5.54 & 11.8 & 18.06 \\
\hline K3 & 2666.57 & 6100.17 & 9533.78 \\
\hline K4 & 0 & 1.81 & 6.76 \\
\hline $\mathrm{K} 4 \mathrm{C}$ & 0 & 0.2 & 0.63 \\
\hline L1 & 200.45 & 663.13 & 1125.81 \\
\hline L10.1 & 0 & 39.74 & 181.56 \\
\hline L10.2 & 0 & 0 & 187.91 \\
\hline L10.3 & 0 & 0 & 0 \\
\hline L10.4 & 0 & 0 & 0 \\
\hline L2.1 & 0 & 33.03 & 78.11 \\
\hline $\mathrm{L} 2.2$ & 3958.69 & 8987.53 & $14,016.38$ \\
\hline $\mathrm{L} 2.2 \mathrm{~B}$ & 2123.86 & 4488.86 & 6853.85 \\
\hline L2.3 & 804.48 & 2653.96 & 4503.45 \\
\hline L2.3B & 323.99 & 1182.08 & 2040.18 \\
\hline L2.4 & 108.42 & 313.94 & 519.45 \\
\hline L3.1 & 5345.67 & $14,166.71$ & $22,987.74$ \\
\hline L3.2 & 837 & 1831.43 & 2825.87 \\
\hline L3.3 & 2899.03 & 8299.58 & $13,700.14$ \\
\hline L3.4 & 339.23 & 876.46 & 1413.68 \\
\hline L4 & 692.64 & 2775.46 & 4858.28 \\
\hline L5.1 & 4593.16 & $18,720.38$ & $32,847.59$ \\
\hline L5.2 & 0 & 20.67 & 92.69 \\
\hline L5.3 & 6.65 & 131.09 & 255.54 \\
\hline L5.4 & 26.17 & $12,944.73$ & $25,863.28$ \\
\hline L6.1 & 0 & 31.75 & 141.96 \\
\hline L6.2 & 80.85 & 255.89 & 430.92 \\
\hline L6.3 & 125.08 & 250.16 & 375.24 \\
\hline L6.4 & 259.96 & 657.87 & 1055.78 \\
\hline L6.5A & 0 & 0 & 7.52 \\
\hline L6.5B & 504.85 & 1283.43 & 2062.01 \\
\hline L7.1 & 2353.78 & 5783.27 & 9212.76 \\
\hline L7.2 & 579.89 & 1265.08 & 1950.26 \\
\hline L7.3 & 503.59 & 1908.06 & 3312.52 \\
\hline L7.4 & 30.19 & 60.38 & 90.57 \\
\hline L8.1A & 0 & 0 & 66.88 \\
\hline L8.1B & 340.72 & 1494.53 & 2648.35 \\
\hline L8.2 & 26.25 & 62.67 & 99.08 \\
\hline L8.3 & 4.49 & 13.71 & 22.94 \\
\hline L9.1 & 0 & 0 & 2491.47 \\
\hline L9.2 & 0 & 382.52 & 3479.12 \\
\hline L9.3 & 0 & 0 & 49.56 \\
\hline
\end{tabular}


Table A2. Cont.

\begin{tabular}{|c|c|c|c|}
\hline Habitat & $\begin{array}{c}\text { Required Area to Complete } \\
\text { for Scenario } 25 \%\end{array}$ & $\begin{array}{c}\text { Required Area to Complete } \\
\text { for Scenario } 50 \%\end{array}$ & $\begin{array}{l}\text { Required Area to Complete } \\
\text { for Scenario } 75 \%\end{array}$ \\
\hline M1.1 & 785.87 & 2113.59 & 3441.31 \\
\hline M1.2 & 5.75 & 14.53 & 23.3 \\
\hline M1.3 & 23.24 & 51.66 & 80.08 \\
\hline M1.4 & 0 & 88.38 & 190.05 \\
\hline M1.5 & 13.45 & 39.02 & 64.58 \\
\hline M1.6 & 1.52 & 6.4 & 11.28 \\
\hline M1.7 & 293.47 & 1046.7 & 1799.92 \\
\hline M1.8 & 0.62 & 1.25 & 1.87 \\
\hline M2.1 & 20.47 & 111.51 & 202.56 \\
\hline M2.2 & 0 & 0 & 0 \\
\hline M2.3 & 0.06 & 0.83 & 1.6 \\
\hline M2.4 & 0.89 & 1.78 & 2.66 \\
\hline M3 & 0 & 0.14 & 3.16 \\
\hline M4.1 & 0.1 & 12.6 & 25.1 \\
\hline M4.3 & 0.16 & 0.32 & 0.47 \\
\hline M5 & 17.87 & 45.13 & 72.38 \\
\hline M6 & 1.53 & 4.54 & 7.55 \\
\hline M7 & 5.26 & 11.81 & 18.35 \\
\hline R1.1 & 0.41 & 1.58 & 2.74 \\
\hline $\mathrm{R} 1.2$ & 3.09 & 8.5 & 13.9 \\
\hline $\mathrm{R} 1.3$ & 0.26 & 1.95 & 3.65 \\
\hline R1.4 & 16.61 & 84.97 & 153.34 \\
\hline R1.5 & 0 & 0 & 0 \\
\hline $\mathrm{R} 2.1$ & 3.53 & 7.86 & 12.19 \\
\hline $\mathrm{R} 2.2$ & 0 & 148.27 & 379.25 \\
\hline R2.3 & 0 & 48.39 & 439.55 \\
\hline R2.4 & 0 & 0 & 0.74 \\
\hline R3.1 & 0 & 0 & 0 \\
\hline R3.2 & 0 & 0 & 73.35 \\
\hline R3.3 & 0 & 0 & 6.45 \\
\hline R3.4 & 22.89 & 92.8 & 162.71 \\
\hline S1.1 & 5.51 & 14.5 & 23.49 \\
\hline S1.2 & 0 & 239.36 & 490.5 \\
\hline S1.3 & 2.12 & 5.58 & 9.04 \\
\hline S1.4 & 0.34 & 0.75 & 1.15 \\
\hline S1.5 & 0 & 1.72 & 3.49 \\
\hline S2A & 0 & 1.33 & 3.89 \\
\hline S2B & 0.33 & 6.15 & 11.97 \\
\hline S3 & 0 & 0.08 & 0.29 \\
\hline $\mathrm{T} 1.1$ & $13,621.79$ & $30,105.75$ & $46,589.72$ \\
\hline $\mathrm{T} 1.10$ & 26.07 & 68.54 & 111.01 \\
\hline $\mathrm{T} 1.2$ & 854.24 & 2297.14 & 3740.04 \\
\hline $\mathrm{T} 1.3$ & 3218.1 & 7073.43 & $10,928.75$ \\
\hline T1.4 & 1216.43 & 2710.6 & 4204.77 \\
\hline $\mathrm{T} 1.5$ & 1898.13 & 4796.58 & 7695.03 \\
\hline T1.6 & 754.68 & 1866.82 & 2978.96 \\
\hline $\mathrm{T} 1.7$ & 90.84 & 182.66 & 274.48 \\
\hline T1.8 & 0.8 & 1.6 & 2.4 \\
\hline T1.9 & 428.09 & 1131.67 & 1835.25 \\
\hline $\mathrm{T} 2.1$ & 0 & 0 & 0.91 \\
\hline $\mathrm{T} 2.2$ & 32.92 & 110.33 & 187.74 \\
\hline $\mathrm{T} 2.3$ & 156.39 & 823.79 & 1491.19 \\
\hline T3.1 & 0 & 18.8 & 44.79 \\
\hline T3.2 & 0 & 6.05 & 12.99 \\
\hline T3.3 & 8.74 & 71.65 & 134.57 \\
\hline T3.3D & 69.59 & 183.03 & 296.46 \\
\hline
\end{tabular}


Table A2. Cont.

\begin{tabular}{|c|c|c|c|}
\hline Habitat & $\begin{array}{c}\text { Required Area to Complete } \\
\text { for Scenario } 25 \%\end{array}$ & $\begin{array}{l}\text { Required Area to Complete } \\
\text { for Scenario } 50 \%\end{array}$ & $\begin{array}{l}\text { Required Area to Complete } \\
\text { for Scenario } 75 \%\end{array}$ \\
\hline T3.4 & 0 & 0 & 96.96 \\
\hline T3.4B & 19.31 & 42.53 & 65.75 \\
\hline $\mathrm{T} 3.4 \mathrm{D}$ & 491.25 & 1440.75 & 2390.25 \\
\hline T3.5A & 0.81 & 4.08 & 7.35 \\
\hline T3.5B & 156.99 & 323.8 & 490.61 \\
\hline $\mathrm{T} 4.1$ & 2.91 & 16.34 & 29.77 \\
\hline $\mathrm{T} 4.2$ & 42.07 & 101.65 & 161.24 \\
\hline T5.1 & 4.95 & 10.29 & 15.63 \\
\hline T5.2 & 16.44 & 34.28 & 52.13 \\
\hline T5.3 & 62.09 & 157 & 251.92 \\
\hline T5.4 & 16.31 & 32.61 & 48.92 \\
\hline T5.5 & 128.61 & 266.9 & 405.18 \\
\hline T6.1 & 1.12 & 4.78 & 8.44 \\
\hline T6.2 & 20.89 & 49.49 & 78.08 \\
\hline $\mathrm{T} 7$ & 1.39 & 7.8 & 14.21 \\
\hline T8.1 & 0 & 17.64 & 38.53 \\
\hline $\mathrm{T} 8.2$ & 84.26 & 246.4 & 408.53 \\
\hline T8.3 & 3.57 & 13.62 & 23.67 \\
\hline V1 & 10.63 & 22.15 & 33.67 \\
\hline V1F & 468.25 & 1332.24 & 2196.23 \\
\hline V1G & 2202.71 & 5212.52 & 8222.33 \\
\hline $\mathrm{V} 2$ & 30.58 & 64.2 & 97.81 \\
\hline V3 & 0 & 0 & 1.3 \\
\hline V4A & 259.51 & 745.05 & 1230.6 \\
\hline V4B & 598.54 & 1462.26 & 2325.98 \\
\hline V5 & 3.16 & 6.35 & 9.53 \\
\hline V6 & 0 & 0 & 0 \\
\hline Total & $58,263.36$ & $165,993.71$ & $280,134.57$ \\
\hline
\end{tabular}

Table A3. Full name and code of nature and near-nature habitats according to the Habitat Catalogue of the Czech Republic [36] and inclusion of these habitats into the system Natura 2000 as Special Areas of Conservation.

\begin{tabular}{ccc}
\hline Name of Habitats of the CR & Habitats of the CZ & Natura 2000 Habitats \\
\hline Wind-swept alpine grasslands & $\mathrm{A} 1.1$ & 6150 \\
Closed alpine grasslands & $\mathrm{A} 1.2$ & 6150 \\
Alpine heathlands & $\mathrm{A} 2.1$ & 4060 \\
Subalpine Vaccinium vegetation & $\mathrm{A} 2.2$ & 4060 \\
Snow beds & $\mathrm{A} 3$ & 6150 \\
Subalpine tall grasslands & $\mathrm{A} 4.1$ & 6430 \\
Subalpine tall-forb vegetation & $\mathrm{A} 4.2$ & 6430 \\
Subalpine tall-fern vegetation & $\mathrm{A} 4.3$ & 6430 \\
Cliff vegetation in the Sudeten cirques & $\mathrm{A} 5$ & 8220 \\
Acidophilous vegetation of alpine boulder screes & $\mathrm{A} 6 \mathrm{~A}$ & 8110 \\
Acidophilous vegetation of alpine cliffs & $\mathrm{A} 6 \mathrm{~B}$ & 8220 \\
Pinus mugo scrub & $\mathrm{A} 7$ & 4070 \\
Salix lapponum subalpine scrub & $\mathrm{A} 8.1$ & 4080 \\
Subalpine deciduous tall scrub & $\mathrm{A} 8.2$ & 4080 \\
Willow cars & $\mathrm{K} 1$ & - \\
Killow scrub of loamy and sandy river banks & $\mathrm{K} 2.1$ & - \\
Willow scrub of river gravel banks & $\mathrm{K} 2.2$ & 3240 \\
Tall mesic and xeric scrub & $\mathrm{K} 3$ & - \\
Low xeric scrub, primary vegetation on rock outcrops with & $\mathrm{K} 4 \mathrm{~A}$ & $40 \mathrm{~A} 0$ \\
Cotoneaster spp. & $\mathrm{K} 4 \mathrm{~B}$ & $40 \mathrm{~A} 0$
\end{tabular}


Table A3. Cont.

\begin{tabular}{|c|c|c|}
\hline Name of Habitats of the CR & Habitats of the CZ & Natura 2000 Habitats \\
\hline Alder cars & L1 & - \\
\hline Birch mire forests & L10.1 & 91D0 \\
\hline Pine mire forests with Vaccinium & L10.2 & 91D0 \\
\hline Pine forests of continental mires with Eriophorum & L10.3 & 91D0 \\
\hline Pinus rotundata bog forests & L10.4 & 91D0 \\
\hline Montane grey alder galleries & L2.1 & 91E0. \\
\hline Ash-alder alluvial forests & $\mathrm{L} 2.2$ & 91E0. \\
\hline Hardwood forests of lowland rivers & $\mathrm{L} 2.3$ & $91 \mathrm{~F} 0$ \\
\hline Willow-poplar forests of lowland rivers & L2.4 & 91E0. \\
\hline Hercynian oak-hornbeam forests & L3.1 & 9170 \\
\hline Polonian oak-hornbeam forests & L3.2 & 9170 \\
\hline Pannonian-Carpathian oak-hornbeam forests & L3.3A & 91G0 \\
\hline West Carpathian oak-hornbeam forests & L3.3B & 9170 \\
\hline Pannonian oak-hornbeam forests & L3.4 & 91G0 \\
\hline Ravine forests & L4 & 9180 \\
\hline Herb-rich beech forests & L5.1 & 9130 \\
\hline Montane sycamore-beech forests & L5.2 & 9140 \\
\hline Limestone beech forests & L5.3 & 9150 \\
\hline Acidophilous beech forests & L5.4 & 9110 \\
\hline Peri-Alpidic basiphilous thermophilous oak forests & L6.1 & $91 \mathrm{HO}$ \\
\hline Pannonian thermophilous oak forests on loess & L6.2 & $91 \mathrm{I} 0$ \\
\hline Pannonian thermophilous oak forests on sand & L6.3 & 91I0 \\
\hline Central European basiphilous thermophilous oak forests & L6.4 & 91I0 \\
\hline Acidophilous thermophilous oak forests with Genista pilosa & L6.5A & $91 \mathrm{I} 0$ \\
\hline Acidophilous thermophilous oak forests without Genista pilosa & L6.5B & - \\
\hline Dry acidophilous oak forests & L7.1 & - \\
\hline Wet acidophilous oak forests & L7.2 & 9190 \\
\hline Subcontinental pine-oak forests & L7.3 & - \\
\hline Acidophilous oak forests on sand & L7.4 & - \\
\hline Boreo-continental pine forests with lichens on sand & L8.1A & $91 \mathrm{~T} 0$ \\
\hline Boreo-continental pine forests, other stands & L8.1B & - \\
\hline Forest-steppe pine forests & L8.2 & 91U0 \\
\hline Peri-Alpidic serpentine pine forests & L8.3 & - \\
\hline Montane Calamagrostis spruce forests & L9.1 & 9410 \\
\hline Bog spruce forests & L9.2A & 9410 \\
\hline Waterlogged spruce forests & L9.2B & 9410 \\
\hline Montane Athyrium spruce forests & L9.3 & 9410 \\
\hline Reed beds of eutrophic still waters & M1.1 & - \\
\hline Halophilous reed and sedge beds & M1.2 & - \\
\hline Eutrophic vegetation of muddy substrata & M1.3 & - \\
\hline Riverine reed vegetation & M1.4 & - \\
\hline Reed vegetation of brooks & M1.5 & - \\
\hline Mesotrophic vegetation of muddy substrata & M1.6 & 7140 \\
\hline Tall-sedge beds & M1.7 & - \\
\hline Calcareous fens with Cladium mariscus & M1.8 & 7210 \\
\hline Vegetation of exposed fishpond bottoms & M2.1 & 3130 \\
\hline Annual vegetation on wet sand & M2.2 & 3130 \\
\hline Vegetation of exposed bottoms in warm areas & M2.3 & 3130 \\
\hline Vegetation of annual halophilous grasses & M2.4 & - \\
\hline Vegetation of perennial amphibious herbs & M3 & 3130 \\
\hline Unvegetated river gravel banks & M4.1 & - \\
\hline River gravel banks with Myricaria germanica & M4.2 & 3230 \\
\hline River gravel banks with Calamagrostis pseudophragmites & M4.3 & 3220 \\
\hline Petasites fringes of montane brooks & M5 & 6430 \\
\hline Muddy river banks & M6 & 3270 \\
\hline Herbaceous fringes of lowland rivers & M7 & 6430 \\
\hline Meadow springs with tufa formation & R1.1 & 7220 \\
\hline Meadow springs without tufa formation & $\mathrm{R} 1.2$ & - \\
\hline Forest springs with tufa formation & $\mathrm{R} 1.3$ & 7220 \\
\hline Forest springs without tufa formation & R1.4 & - \\
\hline Subalpine springs & R1.5 & - \\
\hline
\end{tabular}


Table A3. Cont.

\begin{tabular}{|c|c|c|}
\hline Name of Habitats of the CR & Habitats of the $\mathrm{CZ}$ & Natura 2000 Habitats \\
\hline Calcareous fens & R2.1 & 7230 \\
\hline Acidic moss-rich fens & $\mathrm{R} 2.2$ & 7140 \\
\hline Transitional mires & $\mathrm{R} 2.3$ & 7140 \\
\hline Peatsoils with Rhynchospora alba & $\mathrm{R} 2.4$ & 7150 \\
\hline Open raised bogs & R3.1 & 7110 \\
\hline Raised bogs with Pinus mugo & R3.2 & 91D0 \\
\hline Bog hollows & R3.3 & 7110 \\
\hline Degraded raised bogs & R3.4 & 7120 \\
\hline Chasmophytic vegetation of calcareous cliffs and boulder screes & S1.1 & 8210 \\
\hline Chasmophytic vegetation of siliceous cliffs and boulder screes & $\mathrm{S} 1.2$ & 8220 \\
\hline Tall grasslands on rock ledges & S1.3 & - \\
\hline Tall-forb vegetation of fine-soil-rich boulder screes & S1.4 & - \\
\hline Ribes alpinum scrub on cliffs and boulder screes & S1.5 & - \\
\hline Mobile screes of basic rocks & S2A & 8160 \\
\hline Mobile screes of acidis rocks & S2B & 8150 \\
\hline Caves open to the public & S3A & - \\
\hline Caves not open to the public & S3B & 8310 \\
\hline Mesic Arrhenatherum meadows & $\mathrm{T} 1.1$ & 6510 \\
\hline Vegetation of wet disturbed soils & $\mathrm{T} 1.10$ & - \\
\hline Montane Trisetum meadows & $\mathrm{T} 1.2$ & 6520 \\
\hline Cynosurus pastures & $\mathrm{T} 1.3$ & - \\
\hline Alluvial Alopecurus meadows & $\mathrm{T} 1.4$ & - \\
\hline Wet Cirsium meadows & $\mathrm{T} 1.5$ & - \\
\hline Wet Filipendula grasslands & T1.6 & 6430 \\
\hline Continental inundated meadows & $\mathrm{T} 1.7$ & 6440 \\
\hline Continental tall-forb vegetation & $\mathrm{T} 1.8$ & 6430 \\
\hline Intermittently wet Mollinia meadows & T1.9 & 6410 \\
\hline Subalpine Nardus grasslands & $\mathrm{T} 2.1$ & 6230 \\
\hline Montane Nardus grasslands with alpine species & $\mathrm{T} 2.2$ & 6230 \\
\hline $\begin{array}{l}\text { Submontane and montane Nardus grasslands with scattered } \\
\text { Juniperus communis vegetation }\end{array}$ & $\mathrm{T} 2.3 \mathrm{~A}$ & 5130 \\
\hline $\begin{array}{l}\text { Submontane and montane Nardus grasslands without Juniperus } \\
\text { communis }\end{array}$ & $\mathrm{T} 2.3 \mathrm{~B}$ & 6230 \\
\hline Rock-outcrop vegetation with Festuca pallens & T3.1 & 6190 \\
\hline Sesleria grasslands & T3.2 & 6190 \\
\hline Sub-Pannonian steppic grasslands & $\mathrm{T} 3.3 \mathrm{~A}$ & 6240 \\
\hline Pannonian loess steppic grasslands & T3.3B & 6250 \\
\hline $\begin{array}{c}\text { Narrow-leaved dry grasslands with significant occurrence of } \\
\text { orchids }\end{array}$ & Т3.3C & 6210 \\
\hline $\begin{array}{c}\text { Narrow-leaved dry grasslands without significant occurrence of } \\
\text { orchids }\end{array}$ & T3.3D & 6210 \\
\hline $\begin{array}{l}\text { Broad-leaved dry grasslands with significant occurrence of } \\
\text { orchids and with Juniperus communis }\end{array}$ & $\mathrm{T} 3.4 \mathrm{~A}$ & 6210 \\
\hline $\begin{array}{c}\text { Broad-leaved dry grasslands without significant occurrence of } \\
\text { orchids and with Juniperus communis }\end{array}$ & T3.4B & 5310 \\
\hline $\begin{array}{c}\text { Broad-leaved dry grasslands with significant occurrence of } \\
\text { orchids and without Juniperus communis }\end{array}$ & $\mathrm{T} 3.4 \mathrm{C}$ & 6210 \\
\hline $\begin{array}{l}\text { Broad-leaved dry grasslands without significant occurrence of } \\
\text { orchids and without Juniperus communis }\end{array}$ & $\mathrm{T} 3.4 \mathrm{D}$ & 6210 \\
\hline $\begin{array}{c}\text { Acidophilous dry grasslands with significant occurrence of } \\
\text { orchids }\end{array}$ & T3.5A & 6210 \\
\hline $\begin{array}{c}\text { Acidophilous dry grasslands without significant occurrence of } \\
\text { orchids }\end{array}$ & T3.5B & 6210 \\
\hline Dry herbaceous fringes & $\mathrm{T} 4.1$ & - \\
\hline Mesic herbaceous fringes & $\mathrm{T} 4.2$ & - \\
\hline Annual vegetation on sandy soils & T5.1 & 2330 \\
\hline Open sand grasslands with Corynephorus canescens & T5.2 & 2330 \\
\hline Festucasand grasslands & T5.3 & 2330 \\
\hline Pannonian sand steppe grasslands & T5.4 & 6260 \\
\hline Acidophilous grasslands on shallow soils & T5.5 & - \\
\hline
\end{tabular}


Table A3. Cont.

\begin{tabular}{|c|c|c|}
\hline Name of Habitats of the CR & Habitats of the CZ & Natura 2000 Habitats \\
\hline $\begin{array}{l}\text { Acidophilous vegetation of vernal therophytes and succulents } \\
\text { with dominance of Jovibarba globifera }\end{array}$ & T6.1A & 8230 \\
\hline $\begin{array}{l}\text { Acidophilous vegetation of vernal therophytes and succulents } \\
\text { without dominance of Jovibarba globifera }\end{array}$ & T6.1B & 8230 \\
\hline $\begin{array}{c}\text { Basiphilous vegetation of vernal therophytes and succulents } \\
\text { with dominance of Jovibarba globifera }\end{array}$ & T6.2A & 6110 \\
\hline $\begin{array}{l}\text { Basiphilous vegetation of vernal therophytes and succulents } \\
\text { without dominance of Jovibarba globifera }\end{array}$ & T6.2B & 6110 \\
\hline Inland salt marshes & $\mathrm{T} 7$ & 1340 \\
\hline $\begin{array}{l}\text { Dry lowland and colline heaths with occurrence of Juniperus } \\
\text { communis }\end{array}$ & T8.1A & 5130 \\
\hline $\begin{array}{l}\text { Dry lowland and colline heaths without occurrence of Juniperus } \\
\text { communis }\end{array}$ & $\mathrm{T} 8.1 \mathrm{~B}$ & 4030 \\
\hline $\begin{array}{l}\text { Secondary submontane and montane heaths with occurrence of } \\
\text { Juniperus communis }\end{array}$ & $\mathrm{T} 8.2 \mathrm{~A}$ & 5130 \\
\hline $\begin{array}{l}\text { Secondary submontane and montane heaths without occurrence } \\
\text { of Juniperus communis }\end{array}$ & $\mathrm{T} 8.2 \mathrm{~B}$ & 4030 \\
\hline Vaccinium vegetation of cliffs and boulder screes & $\mathrm{T} 8.3$ & 4030 \\
\hline $\begin{array}{l}\text { Macrophyte vegetation of naturally eutrophic and mesotrophic } \\
\text { still waters with Hydrocharis morsusranae }\end{array}$ & V1A & 3150 \\
\hline $\begin{array}{l}\text { Macrophyte vegetation of naturally eutrophic and mesotrophic } \\
\text { still waters with Stratiotes aloides }\end{array}$ & V1B & 3150 \\
\hline $\begin{array}{l}\text { Macrophyte vegetation of naturally eutrophic and mesotrophic } \\
\text { still waters with Utricularia australis or } U \text {. vulgaris }\end{array}$ & V1C & 3150 \\
\hline $\begin{array}{l}\text { Macrophyte vegetation of naturally eutrophic and mesotrophic } \\
\text { still waters with Salvinia natans }\end{array}$ & V1D & 3150 \\
\hline $\begin{array}{c}\text { Macrophyte vegetation of naturally eutrophic and mesotrophic } \\
\text { still waters with Aldrovanda vesiculosa }\end{array}$ & V1E & 3150 \\
\hline $\begin{array}{l}\text { Macrophyte vegetation of naturally eutrophic and mesotrophic } \\
\text { still waters without species specific to V1A-V1E }\end{array}$ & $\mathrm{V} 1 \mathrm{~F}$ & 3150 \\
\hline $\begin{array}{c}\text { Macrophyte vegetation of naturally eutrophic and mesotrophic } \\
\text { still waters without macrophyte species valuable for nature } \\
\text { conservation }\end{array}$ & V1G & - \\
\hline $\begin{array}{c}\text { Macrophyte vegetation of shallow still waters with dominant } \\
\text { Batrachium spp. }\end{array}$ & $\mathrm{V} 2 \mathrm{~A}$ & - \\
\hline $\begin{array}{c}\text { Macrophyte vegetation of shallow still waters with dominant } \\
\text { Hottonia palustris }\end{array}$ & V2B & - \\
\hline Macrophyte vegetation of shallow still waters, other stands & $\mathrm{V} 2 \mathrm{C}$ & - \\
\hline Macrophyte vegetation of oligotrophic lakes and pools & V3 & 3160 \\
\hline $\begin{array}{l}\text { Macrophyte vegetation of water streams with currently present } \\
\text { aquatic macrophytes }\end{array}$ & $\mathrm{V} 4 \mathrm{~A}$ & 3260 \\
\hline $\begin{array}{c}\text { Macrophyte vegetation of water streams with potential } \\
\text { occurrence of aquatic macrophytes or with natural or } \\
\text { semi-natural bed }\end{array}$ & V4B & 3260 \\
\hline Charophyceae vegetation & V5 & 3140 \\
\hline Isoëtes vegetation & V6 & 3130 \\
\hline
\end{tabular}

\section{References}

1. Ripple, W.J.; Wolf, C.; Newsome, T.M.; Galetti, M.; Alamgir, M.; Crist, E.; Mahmoud, M.I.; Laurance, W.F. World scientists' warning to humanity: A second notice. BioScience 2017, 67, 1026-1028. [CrossRef]

2. Intergovernmental Panel on Climate Change (IPCC). Global Warming of $1.5^{\circ} \mathrm{C}$. An IPCC Special Report on the Impacts of Global Warming of $1.5^{\circ} \mathrm{C}$ above Pre-Industrial Levels and Related Global Greenhouse Gas Emission Pathways, in the Context of Strengthening the Global Response to the Threat of Climate Change; Sustainable Development, and Efforts to Eradicate Poverty; World Meteorological Organization: Geneva, Switzerland, 2019.

3. Chan, K.M.A.; Shaw, M.R.; Cameron, D.R.; Underwood, E.C.; Daily, G.C. Conservation planning for ecosystem services. PLoS Biol. 2006, 4, e379. [CrossRef] [PubMed] 
4. Carvalho, S.B.; Brito, J.C.; Crespo, E.G.; Watts, M.E.; Possingham, H.P. Conservation planning under climate change: Toward accounting for uncertainty in predicted species distributions to increase confidence in conservation investments in space and time. Biol. Conserv. 2011, 144, 2020-2030. [CrossRef]

5. Levin, N.; Mazor, T.; Brokovich, E.; Jablon, P.E.; Kark, S. Sensitivity analysis of conservation targets in systematic conservation planning. Ecol. Appl. 2015, 25, 1997-2010. [CrossRef]

6. Meerman, J. National Protected Area Systems Analysis, MARXAN Analysis. 2005. Available online: http://biological-diversity.info/Downloads/NPAPSP/MARXANanalysis.pdf (accessed on 27 December 2019).

7. Munro, K.G. Evaluating Marxan as a Terrestrial Conservation Planning Tool. Ph.D. Thesis, The University of British Columbia, Vancouver, BC, Canada, 2006.

8. UNEP Convention of Biological Diversity (CBD). Decisions Adopted by the Conference of Parties to the Convention on Biological Diversity at Its Tenth Meeting; UNEP Convention of Biological Diversity: Nagoya, Japan, 2010.

9. Venter, O.; Fuller, R.A.; Segan, D.B.; Carwardine, J.; Brooks, T.; Butchart, S.H.; Di Marco, M.; Iwamura, T.; Joseph, L.; O'Grady, D.; et al. Targeting global protected area expansion for imperiled biodiversity. PLoS Biol. 2014, 12, e1001891. [CrossRef]

10. Shriner, S.A.; Wilson, K.R.; Flather, C.H. Reserve networks based on richness hotspots and representation vary with scale. Ecol. Appl. 2006, 16, 1660-1673. [CrossRef]

11. Margules, C.R.; Pressey, R.L. Systematic conservation planning. Nature 2000, 405, 243-253. [CrossRef]

12. Levin, N.; Coll, M.; Fraschetti, S.; Gal, G.; Giakoumi, S.; Göke, C.; Heymans, J.J.; Katsanevakis, S.; Mazor, T.; Öztürk, B.; et al. Review of biodiversity data requirements for systematic conservation planning in the Mediterranean Sea. Mar. Ecol. Prog. Ser. 2014, 508, 261-281. [CrossRef]

13. Burian, J.; Št'astný, S.; Brus, J.; Pechanec, V.; Voženílek, V. Urban Planner: Model for optimal land use scenario modelling. Geografie 2015, 120, 330-353.

14. Ball, R.I.; Possingham, H.P.; Watts, M.E. Marxan and Relatives: Software for spatial conservation prioritization. In Spatial Conservation Prioritization. Quantitative Methods and Computational Tools; Moilanen, A., Wilson, K.A., Possingham, H.P., Eds.; Oxford University Press: Oxford, UK, 2009; pp. 185-195.

15. Geselbracht, L.; Torres, R.; Cumming, G.S.; Dorfman, D.; Beck, M. Marine/Estuarine Site Assessment for Florida: A Framework for Site Prioritization; Final Report for Florida's Wildlife Legacy Initiative, a Program of the Florida Fish and Wildlife Conservation Commission; The Nature Conservancy: Gainesville, FL, USA, 2005.

16. Reining, C.; Beazley, K.; Doran, P.; Bettigole, C. From the Adirondacks to Acadia: A Wildlands Network Design for the Greater Northern Appalachians; Wildlands Project Special Paper 7; Wildlands Project: Richmond, VT, USA, 2006.

17. Wilson, K.A.; Meijaard, E.; Drummond, S.; Grantham, H.S.; Boitani, L. Conserving biodiversity in production landscapes. Ecol. Appl 2010, 20, 1721-1732. [CrossRef]

18. Green, A.; Smith, S.E.; Lipsett-Moore, G.; Groves, C.; Peterson, N.; Sheppard, S.; Lokani, P.; Hamilton, R.; Almany, J.; Aitsi, J.; et al. Designing a resilient network of marine protected areas for Kimbe Bay, Papua New Guinea. Oryx 2009, 43, 488-498. [CrossRef]

19. Ministry of the Environment of the Czech Republic. Act No 114/1992 Coll., on the Conservation of Nature and Landscape, of the Czech Republic; Ministry of the Environment of the Czech Republic: Prague, Czech Republic, 1992.

20. Pechanec, V.; Machar, I.; Štěrbová, L.; Prokopová, M.; Kilianová, H.; Chobot, K.; Cudlín, P. Monetary Valuation of Natural Forest Habitats in Protected Areas. Forests 2017, 8, f8110427. [CrossRef]

21. UNEP-WCMC, Protected Area Profile for Czech Republic from the World Database of Protected Areas. Available online: https://www.protectedplanet.net/country/CZ (accessed on 27 December 2019).

22. Ministry of the Environment of the Czech Republic. Decree 395/1992 Coll. Decree of the Ministry of the Environment of the Czech Republic Implementing Certain Provisions of Czech National Council Act No. 114/1992 Coll., On Nature and Landscape Protection; Ministry of the Environment of the Czech Republic: Prague, Czech Republic, 1992.

23. Ministry of the Environment of the Czech Republic. Decree 45/2018 Coll. Decree on care plans, principles of care and documents for the announcement, registration and labeling of protected areas of the Czech Republic; Ministry of the Environment of the Czech Republic: Prague, Czech Republic, 2018.

24. European Commission. Directive 2009/147/EC of the European Parliament and of the Council of 30 November 2009 on the Conservation of Wild Birds; Birds Directive; European Commission: Brussels, Belgium, 2009. 
25. European Commission. Council Directive 92/43/EEC of 21 May 1992 on the Conservation of Natural Habitats and of Wild Fauna and Flora; Habitats Directive; European Commission: Brussels, Belgium, 1992.

26. NCA CR. Nature Protection Network and NATURA 2000 in the Czech Republic. Available online: http://www.ochranaprirody.cz/en/ (accessed on 2 December 2019).

27. European Environmental Agency (EEA). Protected Areas in Europe-An Overview; European Environmental Agency: Copenhagen, Denmark, 2012.

28. EIONET. A Short Guide to the Eionet; EIONET: Kopenhagen, Denmark, 2019.

29. Game, E.T.; Grantham, H.S. Marxan User Manual, For Marxan version 1.8.10; University of Queensland: St. Lucia, QLD, Australia; Pacific Marine Analysis and Research Association: Vancouver, BC, Canada, 2008.

30. Cudlín, P.; Pechanec, V.; Štěrbová, L.; Cudlín, O.; Purkyt, J. Integrated approach to the mitigation of biodiversity lost in Central Europe. In Ecological Integrity and Land Use. Sovereignty, Governance, Displacements and Land Grabs, 1st ed.; Westra, L., Bosselmann, K., Zabrano, V., Eds.; Nova Science Publishers: New York, NY, USA, 2019; pp. 75-86.

31. Seják, J.; Dejmal, I.; Petříček, V.; Cudlín, P.; Míchal, I.; Černý, K.; Kučera, T.; Vyskot, I.; Strejček, J.; Cudlínová, E.; et al. Hodnocení a oceňování biotopi České republiky (Assessment and Valuation of Habitats Czech Republic); Czech Environmental Institute, Ministry of the Environment: Prague, Czech Republic, 2003.

32. Seják, J.; Cudlín, P. On measuring the natural and environmental resource value and damages. Stud. Ecol. 2010, 4, 53-68.

33. Pechanec, V.; Machar, I.; Pohanka, T.; Opršal, Z.; Petrovič, F.; Švajda, J.; Šálek, L.; Chobot, K.; Filippovová, J.; Cudlín, P.; et al. Effectiveness of Natura 2000 system for habitat types protection: A case study from the Czech Republic. Nat. Conserv. 2017, 24, 21-41. [CrossRef]

34. Ardron, J.A.; Possingham, H.P.; Klein, C.J. (Eds.) Marxan Good Practices Handbook; Pacific Marine Analysis and Research Association: Victoria, BC, Canada, 2010.

35. Nature Conservation Agency in the Czech Republic (NCA CR). Vrstva Mapování Biotopů, Elektronická Georeferencovaná Database, Verze 2014 (Habitat Mapping Layer, Electronic Georeferenced Database, Version 2014); Rozšíření Přírodních a Přírodě Blízkých Stanovišt' na Území ČR (Distribution of Natural and Near-Natural Habitats in the Czech Republic); Nature Conservation Agency in the Czech Republic: Prague, Czech Republic, 2014.

36. Chytrý, M.; Kučera, T.; Kočí, M.; Grulich, V.; Lustyk, P. (Eds.) Katalog Biotopů České Republiky (Habitat Catalogue of the Czech Republic), 2nd ed.; Nature Conservation Agency in the Czech Republic: Prague, Czech Republic, 2010.

37. Guth, J. Metodika Mapování Biotopu Soustavy Natura 2000 a Smaragd, Metodiky Podrobného a Kontextového Mapování (Methodology for Habitat Mapping of the Natura 2000 and Emerald, Methods of Detailed and Contextual Mapping); Nature Conservation Agency in the Czech Republic: Prague, Czech Republic, 2002.

38. Lustyk, P.; Guth, J. Metodika Aktualizace Vrstoy Mapováni Biotopů (Methodology of the Habitat Mapping in the Czech Republic); Nature Conservation Agency in the Czech Republic: Prague, Czech Republic, 2011.

39. Dr Bob Smith's Website. Available online: https://anotherbobsmith.wordpress.com/software/cluz/ (accessed on 27 December 2019).

40. Bastian, O. The role of biodiversity in supporting ecosystem services in Natura 2000 sites. Ecol. Indic. 2013, 24, 12-22. [CrossRef]

41. Lustyk, P.; Oušková, V.; Kratochvílová, L.; Chobot, K. Zpráva o stavu biotopů 2013, Hodnocení stavu a trendů evropsky významných typů přírodních stanovišt' (Report on the Status of Habitats in the year 2013, Assessment of the Status and Trends of Habitats of Community Importance). Ochr. Přrir. 2014, 3, 30-33.

42. Křenová, Z.; Kindlmann, P. Natura 2000—Solution for Eastern Europe or just a good start? The Šumava National Park as a test case. Biol. Conserv. 2015, 186, 268-275. [CrossRef]

43. Sarvašová, Z.; Quiroga, S.; Suárez, C.; Alic, T.; Lukmine, D.; Đorđević, I.; Hrib, M. Understanding the drivers for Natura 2000 payments in forests: A Heckman selection analysis. J. Nat. Conserv. 2018, 46, $28-37$. [CrossRef]

44. Balázsi, A. Grassland management in protected areas-Implementation of the EU biodiversity strategy in certain post-communist countries. Hacquetia 2018, 17, 73-84. [CrossRef]

45. Halada, L.; Evans, D.; Romão, C.; Petersen, J.E. Which habitats of European importance depend on agricultural practices? Biodivers. Conserv. 2011, 20, 2365-2378. [CrossRef] 
46. Cizek, O.; Vrba, P.; Benes, J.; Hrazsky, Z.; Koptik, J.; Kucera, T.; Marhoul, P.; Zamecnik, J.; Konvicka, M. Conservation Potential of Abandoned Military Areas Matches that of Established Reserves: Plants and Butterflies in the Czech Republic. PLoS ONE 2013, 8, e53124. [CrossRef] [PubMed]

47. Warren, S.D.; Buttner, R. Active military training areas as refugia for disturbance-dependent endangered insects. J. Insect. Conserv. 2008, 12, 671-676. [CrossRef]

48. Bonari, G.; Fajmon, K.; Malenovský, I.; Zelený, D.; Holuša, J.; Jongepierová, I.; Kočárek, P.; Konvička, O.; Uřičár̆, J.; Chytrý, M. Management of semi-natural grasslands benefiting both plant and insect diversity: The importance of heterogeneity and tradition. Agric. Ecosyst. Environ. 2017, 246, 243-252. [CrossRef]

49. Mitchley, J.; Jongepierová, I.; Fajmon, K. Regional seed mixtures for the re-creation of species-rich meadows in the White Carpathian Mountains: Results of a 10-yr experiment. Appl. Veg. Sci. 2012, 15, 253-263. [CrossRef]

50. Bauhus, J.; Puettmann, K.; Kühne, C. Close-to-Nature Forest Management in Europe: Does It Support Complexity and Adaptability of Forest Ecosystems. In Managing Forests as Complex Adaptive Systems: Building Resilience to the Challenge of Global Change, 1st ed.; Messier, C., Puettmann, K.J., Coates, K.D., Eds.; Routledge: London, UK, 2013; pp. 187-213.

51. Salvati, L.; Perini, L.; Sabbi, A.; Bajocco, S. Climate Aridity and Land Use Changes: A Regional-Scale Analysis. Geogr. Res. 2017, 50, 193-203. [CrossRef]

52. Bajocco, S.; Salvati, L.; Ricotta, C. Land degradation versus fire: A spiral process? Prog. Phys. Geogr. 2011, 35, 3-18. [CrossRef]

53. Salvati, L.; Zitti, M.; Perini, L. Fifty years on: Long-term patterns of land sensitivity to desertification in Italy. Land Degrad. Dev. 2016, 27, 97-107. [CrossRef]

(C) 2020 by the authors. Licensee MDPI, Basel, Switzerland. This article is an open access article distributed under the terms and conditions of the Creative Commons Attribution (CC BY) license (http://creativecommons.org/licenses/by/4.0/). 